\title{
12. EOCENE SILICEOUS AND CALCAREOUS PHYTOPLANKTON, DEEP SEA DRILLING PROJECT LEG 951
}

\author{
David Bukry, U.S. Minerals Management Service, Scripps Institution of Oceanography²
}

\begin{abstract}
Eocene siliceous and calcareous phytoplankton, with emphasis on silicoflagellates, were studied in 62 samples from DSDP Sites 612 and 613 on the continental slope and rise off New Jersey. The mid-latitude assemblages correlate well with assemblages from California, Peru, and offshore of southern Brazil, but are distinctly different from high-latitude cold-water assemblages of the Falkland Plateau off southern Argentina. Coccoliths and silicoflagellates provide evidence for the presence of a fairly complete middle and upper Eocene sequence, represented by a composite of Sites 612 and 613. A major unconformity occurs at the middle Eocene to upper Eocene contact at Site 612 .

The genus Bachmannocena Locker is emended and proposed as a replacement for genus Mesocena Ehrenberg for ring silicoflagellates. Six new silicoflagellates and one new diatom are described: Bachmannocena apiculata monolineata Bukry, n. subsp., Corbisema amicula Bukry, n. sp., C. bimucronata elegans Bukry, n. subsp., C. hastata incohata Bukry, n. subsp., C. jerseyensis Bukry, n. sp., Dictyocha acuta Bukry, n. sp., and Coscinodiscus eomonoculus Bukry, n. sp. Also, one new replacement name, B. paulschulzii Bukry, nom. nov., and 24 new combinations are proposed for genus Bachmannocena.
\end{abstract}

\section{INTRODUCTION}

Coring on Leg 95, off the coast of New Jersey, recovered a thick section of Eocene biosilica-rich sediment. Silicoflagellates from 62 samples taken from a $160-\mathrm{m}$ thick section at DSDP Site 612 and a 120 -m-thick section at DSDP Site 613 were studied for biostratigraphy, paleobiogeography, and taxonomy. Coccolith stratigraphy at these sites provides a check on silicoflagellate zonal correlation with the recently described Eocene sections in California (Barron et al., 1984), the Rio Grande Rise (Bukry, 1977), and the Falkland Plateau (Shaw and Ciesielski, 1983). The extensive biosilica-rich stratigraphic sections of Sites 612 and 613 cover the major parts of the middle and upper Eocene in a mid-latitude setting. Lower Eocene strata lack siliceous phytoplankton. The main goals of this study were to identify the similarity and contrasts between the Leg 95 assemblages and assemblages of other areas (Fig. 1). Owing to the diverse assemblages, biostratigraphic correlation by key warmand temperate-water species ranges (Bachmannocena apiculata apiculata, Dictyocha hexacantha, D. spinosa, $M a$ crora najae) was straightforward. Relative paleotemperature correlation through the Corbisema/Naviculopsis ratio was less satisfactory, as it appeared that strong dissolution (Site 613) might differentially remove more Corbisema than Naviculopsis.

Taxonomically, use of the genus Bachmannocena Locker is instituted for ring silicoflagellates previously referred to Mesocena, and several other new taxa from the Leg 95 assemblages are described. The main taxonomic highlight is the close reiteration of form and composition be-

\footnotetext{
${ }^{1}$ Poag, C. W., Watts, A. B., et al., Init. Repts. DSDP, 95: Washington (U.S. Govt. Printing Office).

2 Address: U.S. Minerals Management Service (A-015), Scripps Institution of Oceanography, La Jolla, CA 92093.
}

tween the assemblages of Leg 95 and those in California and on the Rio Grande Rise. The coeval assemblages of the Falkland Plateau represent a different cold-water province where the relative abundance of $N$. foliacea (warm) is small compared with that of $N$. constricta (cool).

\section{METHODS AND MATERIALS}

Acid-residue slides (silicoflagellates) and whole-sediment smear slides (coccoliths) were prepared for 62 samples from Cores 16 to 37 from Site 612 and Cores 21 to 38 from Site 613. Light-microscope study and counts were done at magnifications from $200 \times$ to $500 \times$. Silicoflagellate abundance was variable, and up to three slides per sample were used to obtain counts for some sparse samples. To meet time constraints, counts of 100 specimens per sample were used as the general goal to establish quantitative trends. Fragmented silicoflagellates were mentally accumulated until they could be tallied as whole specimens. Tilted, obscured, and taxonomically ambiguous specimens were tallied as indeterminate spp. to provide fair generic numbers. Coccolith determinations were made from light-microscope smear slides of original sediment for the same samples used for silicoflagellates. Assemblages were studied at magnifications of $500 \times$ to $1000 \times$. Coccolith zonation is based on the low-latitude zonation developed for DSDP core material (Bukry, 1973b, 1975a; Okada and Bukry, 1980). Silicoflagellates are also zoned and correlated according to the stratigraphic relations synthesized for low-latitude DSDP cores (Bukry, 1981a) and expanded for the Kellogg Shale of California (Barron et al., 1984).

\section{SUMMARIES OF PHYTOPLANKTON OBSERVATIONS AT LEG 95 SITES 612 AND 613}

\section{Site $612\left(38^{\circ} 49.21^{\prime} \mathrm{N}, 7^{\circ} 46.43^{\prime} \mathrm{W}\right.$; water depth $1404 \mathrm{~m})$}

Site 612 was drilled on the New Jersey Continental Slope to provide a relatively uninterrupted section for a stratigraphic framework. The hemipelagic sediment of the middle and upper Eocene is especially rich in biosilica. Silicoflagellates are generally common to abundant through Cores 612-17 to 612-33. The associated coccoliths are abundant and diverse, with primary guide fossils, such as Chiasmolithus gigas, C. grandis, Discoaster 


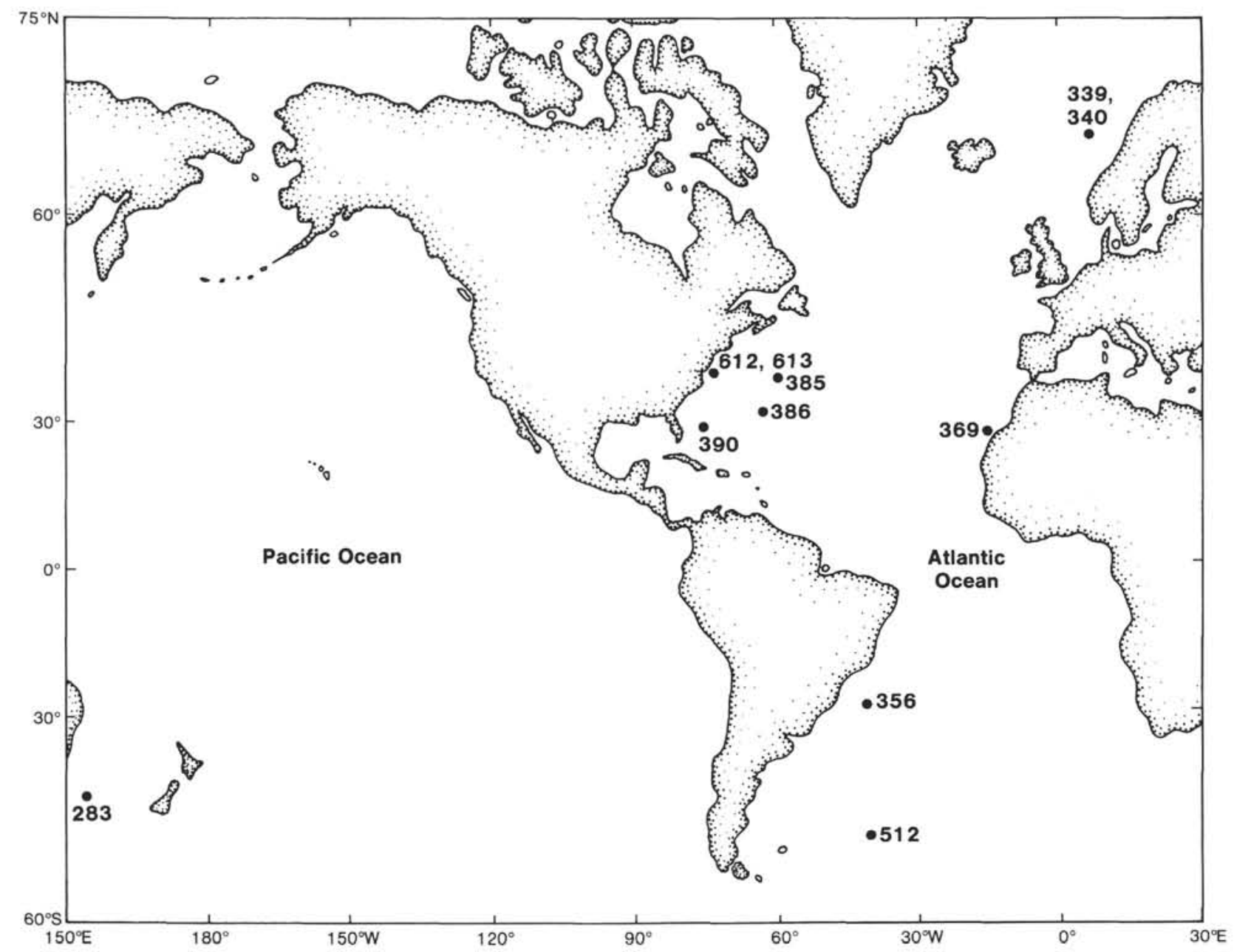

Figure 1. Locations of DSDP sites cited in text.

bifax, and Isthmolithus recurvus, permitting recognition of low-latitude Subzones CP13b to CP15b. No sediment of lower upper Eocene Subzone CP15a was found, although it could be present in the interval between 181 and $185 \mathrm{~m}$ (in Core 612-22), which I did not sample; more detailed shipboard studies of the interval indicated that this subzone is missing (see Valentine, this volume; Poag and Low, this volume). Silicoflagellates show a drastic species change at the level of this gap, which is within the Dictyocha hexacantha Zone. Older assemblages, below the gap, have common Naviculopsis foliacea predominant over $N$. constricta and consistently common Macrora barbadensis. Above the gap, $N$. foliacea and $M$. barbadensis are sparse and sporadic, whereas $N$. constricta is common and persistent.

The oldest assemblages studied from Site 612, Core 612-33, are assigned to the middle Eocene Chiasmolithus gigas Subzone (CP13b) of coccoliths and to the Dictyocha spinosa Subzone of silicoflagellates (Table 1). $\mathrm{Na}$ viculopsis foliacea is the dominant silicoflagellate. Near the top of the $D$. spinosa Subzone in Cores 612-25 and 612-26, Macrora barbadensis becomes abundant. The most characteristic taxa of the $D$. spinosa Subzone at Site 612, such as Corbisema regina, Dictyocha byronalis, Naviculopsis constricta, and N. foliacea, also persist into the overlying Dictyocha hexacantha Zone, which first occurs in the top of Core 612-25. The earliest Dictyocha hexacantha in Core 612-25 is closely followed by the earliest Bachmannocena oamaruensis in Core 61224. The appearance of $B$. oamaruensis and Macrora najae within the Discoaster bifax Subzone (CP14a) of coccoliths matches their appearances in the middle Eocene Kellogg Shale of California and in DSDP Core 356-6 from the Rio Grande Rise of the South Atlantic Ocean (Barron et al., 1984; Bukry, 1977), and thus provides additional means of mid-latitude correlation.

Bachmannocena is fairly sparse in the $D$. hexacantha Zone and $D$. spinosa Subzone intervals of Site 612. The spineless species $B$. oamaruensis and $B$. venusta outnumber the spined specimens of $B$. paulschulzii. The occurrences of common B. apiculata apiculata in Cores 61217 and $612-19$, at abundances from 12 to $22 \%$, are numerically noteworthy, and coincide with the interval (Cores 612-17 to 612-19) where cool-indicating Naviculopsis constricta is most abundant ( 23 to $46 \%$ ).

The upper Eocene part of the section at Site 612 is significant because it provides one of the only records of mid-latitude silicoflagellate assemblages in the coccolith Isthmolithus recurvus Zone (Table 2). The section, from Core $612-21$ to Core $612-17$, also includes the zonal boundary (Dictyocha hexacantha extinction in Core 612-19) between the Corbisema apiculata Zone and the 
Table 1. Middle Eocene silicoflagellates from Site 612 (Cores 612-22 to 612-33), recorded as percent, with total specimens, Corbisema/Naviculopsis ratio, and biostratigraphic zonal assignments.

\begin{tabular}{|c|c|c|c|c|c|c|c|c|c|c|c|c|c|c|c|c|c|c|c|}
\hline \multirow{3}{*}{$\begin{array}{l}\text { Silicoflagellate zone } \mathrm{e}^{\mathrm{a}} \\
\text { Coccolith zone }^{\mathrm{a}} \\
\text { Sub-bottom depth (m) }\end{array}$} & \multicolumn{9}{|c|}{ Dictyocha hexacantha } & \multicolumn{10}{|c|}{ Naviculopsis foliacea (Dictyocha spinosa Subzone) } \\
\hline & \multicolumn{11}{|c|}{ CP14a } & \multicolumn{5}{|c|}{ CP13c } & \multicolumn{3}{|c|}{ CP13b } \\
\hline & 185 & 188 & 191 & 194 & 197 & 200 & 204 & 210 & 214 & 217 & 220 & 223 & 229 & 236 & 242 & 248 & 281 & 290 & 296 \\
\hline Core-Section $^{b}$ & $22-1$ & $22-3$ & $22-5$ & $23-1$ & 23-3 & $23-5$ & $24-1$ & $24-5$ & $25-1$ & $25-3$ & $25-5$ & $26-1$ & $26-5$ & $27-3$ & $28-1$ & $28-5$ & $32-1$ & $33-1$ & 33-5 \\
\hline $\begin{array}{l}\text { Bachmannocena oamaruensis } \\
\text { B. paulschulzii } \\
\text { B. venusta } \\
\text { B. sp. f. B. venusta } \\
\text { B. spp. }\end{array}$ & 2 & 1 & $\begin{array}{l}2 \\
2\end{array}$ & $\begin{array}{l}2 \\
1\end{array}$ & 1 & $\begin{array}{l}2 \\
1\end{array}$ & $\begin{array}{l}1 \\
1\end{array}$ & $\begin{array}{l}3 \\
1\end{array}$ & $\begin{array}{l}2 \\
1\end{array}$ & $\begin{array}{l}2 \\
1\end{array}$ & $\begin{array}{l}1 \\
1\end{array}$ & & $\dot{0}_{2}^{2}$ & 1 & & & 1 & & \\
\hline $\begin{array}{l}\text { Corbisema angularis } \\
\text { C. apiculata } \\
\text { C. bimucronata bimucronata } \\
\text { C. ellipsis } \\
\text { C. exilis }\end{array}$ & $\begin{array}{l}3 \\
1\end{array}$ & 1 & $\begin{array}{l}1 \\
2 \\
1\end{array}$ & & 1 & $\begin{array}{l}3 \\
1\end{array}$ & $\begin{array}{l}1 \\
1 \\
1\end{array}$ & & & 2 & 3 & 1 & & 4 & $\begin{array}{l}3 \\
3\end{array}$ & 12 & $\begin{array}{l}1 \\
2\end{array}$ & 4 & 2 \\
\hline $\begin{array}{l}\text { C. hastata globulata } \\
\text { C. hastata hastata } \\
\text { C. hastata miranda } \\
\text { C. inerrmis ballantina } \\
\text { C. inermis inermis }\end{array}$ & $\begin{array}{l}1 \\
4 \\
1\end{array}$ & 1 & 2 & 1 & & & $\begin{array}{l}1 \\
1\end{array}$ & 1 & 1 & & & 1 & & 1 & 2 & 3 & 10 & 1 & $\begin{array}{r}9 \\
1 \\
1 \\
14 \\
\end{array}$ \\
\hline $\begin{array}{l}\text { C. sp. cf. C. inermis inermis (spines) } \\
\text { C. inermis minor } \\
\text { C. jerseyensis } \\
\text { C. lamellifera } \\
\text { C. sp. cf. C. recta }\end{array}$ & $\begin{array}{l}1 \\
2\end{array}$ & 2 & 1 & $\begin{array}{l}1 \\
2 \\
1\end{array}$ & 2 & & & & & & 1 & 1 & & & & & 1 & 4 & \\
\hline $\begin{array}{l}\text { C. regina } \\
\text { C. regina (bar) } \\
\text { C. triacantha convexa } \\
\text { C. sp. A } \\
\text { C. spp. }\end{array}$ & $\begin{array}{l}5 \\
1\end{array}$ & $\begin{array}{l}4 \\
9\end{array}$ & $\begin{array}{r}11 \\
4\end{array}$ & $\begin{array}{l}5 \\
2\end{array}$ & $\begin{array}{r}1 \\
17\end{array}$ & $\begin{array}{l}1 \\
1\end{array}$ & $\begin{array}{l}6 \\
4\end{array}$ & 12 & $\begin{array}{r}15 \\
3\end{array}$ & 12 & $\begin{array}{l}5 \\
2\end{array}$ & 12 & 14 & 10 & $\begin{array}{r}43 \\
1 \\
5\end{array}$ & $\begin{array}{r}17 \\
8\end{array}$ & $\begin{array}{r}36 \\
6\end{array}$ & 17 & 5 \\
\hline $\begin{array}{l}\text { Dictyocha brevispina s. ampl. } \\
\text { D. byronalis } \\
\text { D. sp. cf. D. byronalis } \\
\text { D. hexacantha } \\
\text { D. spinosa }\end{array}$ & $\begin{array}{r}16 \\
2\end{array}$ & 8 & $\begin{array}{r}14 \\
1 \\
1\end{array}$ & $\begin{array}{r}22 \\
1 \\
2\end{array}$ & $\begin{array}{l}4 \\
1 \\
3\end{array}$ & $\begin{array}{r}18 \\
3 \\
2\end{array}$ & $\begin{array}{l}9 \\
4\end{array}$ & $\begin{array}{l}5 \\
1 \\
2\end{array}$ & $\begin{array}{l}7 \\
1 \\
1\end{array}$ & 11 & 15 & $\begin{array}{r}14 \\
2 \\
1\end{array}$ & 14 & 35 & 24 & 20 & $\begin{array}{l}5 \\
6\end{array}$ & $\begin{array}{l}1 \\
5\end{array}$ & ${ }_{1}^{4}$ \\
\hline $\begin{array}{l}\text { D. spp. (asperoid) } \\
\text { D. spp. (fibuloid) } \\
\text { Distephanus crux s. ampl. } \\
\text { D. sp. c. D. quinquangellus } \\
\text { D. speculum hemisphaericus }\end{array}$ & $\begin{array}{l}1 \\
4\end{array}$ & 1 & 3 & & 2 & 1 & & & & & & & & 1 & 4 & 5 & 1 & 3 & 4 \\
\hline $\begin{array}{l}\text { D. speculum triommata } \\
\text { D. sp. aff. D. speculum speculum (no pikes) } \\
\text { D. spp. } \\
\text { Macrora barbadiensis } \\
\text { M. najae }\end{array}$ & 26 & $\begin{array}{r}1 \\
53 \\
1\end{array}$ & 10 & $\begin{array}{r}1 \\
33 \\
1 \\
\end{array}$ & $\begin{array}{r}52 \\
1 \\
\end{array}$ & 21 & 32 & 38 & 39 & 25 & 15 & 36 & 4 & & 2 & 6 & 1 & 2 & $\begin{array}{l}1 \\
2\end{array}$ \\
\hline $\begin{array}{l}\text { Naviculopsis constricta } \\
\text { N. constricta (semibarred) } \\
\text { N. eobiapiculata }\end{array}$ & 14 & 5 & 17 & 10 & 6 & 22 & $\begin{array}{l}8 \\
1\end{array}$ & 4 & 3 & 5 & 30 & 2 & 4 & 2 & & 2 & 8 & 15 & $\begin{array}{r}15 \\
1 \\
1\end{array}$ \\
\hline N. foliaced & 20 & 13 & 28 & 18 & 15 & 22 & 28 & 33 & 25 & 41 & 24 & 27 & 60 & 37 & 9 & 27 & 17 & 35 & 38 \\
\hline Total Specimens & 200 & 100 & 100 & 200 & 200 & 100 & 100 & 100 & 100 & 100 & 100 & 100 & 50 & 100 & 100 & 100 & 100 & 100 & 100 \\
\hline Corbisema/Naviculopsis ratio & 0.5 & 0.9 & 0.5 & 0.4 & 0.9 & 0.2 & 0.4 & 0.4 & 0.8 & 0.3 & 0.2 & 0.6 & 0.2 & 0.4 & 6.3 & 1.4 & 2.4 & 0.7 & 0.6 \\
\hline
\end{tabular}

Note: $\bullet$ indicates occurrence noted during photography after count completed.

a Zonations are from Okada and Bukry (1980) and Bukry (1981b).

$b$ Each section was sampled at the $100-101 \mathrm{~cm}$ level.

Dictyocha hexacantha Zone. The most unusual aspect of assemblages in the upper Eocene is the persistent occurrence of Macrora stella in Cores 612-17 to 612-21. Previously, this species had been recorded at more than 13 DSDP sites, but always in the Oligocene or Miocene. The only lower Oligocene occurrence reported was at North Atlantic Hole 369A, at a $1 \%$ abundance in the $C$. apiculata Zone (Bukry, 1978a). At Site 612 the maximum abundance is $7 \%$, within the earlier $D$. hexacantha Zone (Core 612-21). These earliest occurrences fill the stratigraphic gap between $M$. stella and its presumed ancestor $M$. barbadensis. Several new taxa of Corbise$m a$ are identified from this upper Eocene section, further indicating that it represents a new addition to the Paleogene silicoflagellate succession. Similarly, two flatbased precursor specimens resembling late Oligocene and Miocene Bachmannocena apiculata curvata occur only in the highest core (612-17). Older taxa, such as Corbi- sema regina and Dictyocha byronalis, are replaced by newer taxa, such as $C$. triacantha mediana and others.

Acid-residue preparations from Core 612-16 contain Miocene silicoflagellate taxa, such as Bachmannocena circulus apiculata and B. diodon nodosa. Together with the occurrence of late Eocene coccolith taxa Discoaster saipanensis and Isthmolithus recurvus in Sample 612$17-1,100-101 \mathrm{~cm}$, this suggests that the Oligocene and lower Miocene are missing, or are limited to only the lower $2 \mathrm{~m}$ of Core $612-16$ or the upper meter of Core 612-17 (see Poag and Low, this volume; Miller and Katz, this volume).

\section{Site $613\left(38^{\circ} 46.26^{\prime} \mathrm{N}, 72^{\circ} 30.43^{\prime} \mathrm{W}\right.$; water depth} $2323 \mathrm{~m}$ )

Site 613 was cored on the upper continental rise off New Jersey to establish the stratigraphic framework for periods of erosional channel formation and to document 
D. BUKRY

Table 2. Upper Eocene silicoflagellates from Site 612 (Cores 612-17 to 612-21), recorded as percent, with total specimens, Corbisema/

Naviculopsis ratio, and biostratigraphic zonal assignments.

\begin{tabular}{|c|c|c|c|c|c|c|c|c|c|c|c|c|c|c|}
\hline \multirow{3}{*}{$\frac{{\text { Silicoflagellate } z o n \mathrm{e}^{\mathrm{a}}}_{\text {Coccolith zone }^{\mathrm{a}}}}{\text { Sub-bottom depth }(\mathrm{m})}$} & \multicolumn{8}{|c|}{ Corbisema apiculata Zone } & \multicolumn{6}{|c|}{ Dictyocha hexacantha Zone } \\
\hline & \multicolumn{14}{|c|}{$\mathrm{CP} 15 \mathrm{~b}$} \\
\hline & 137 & 140 & 143 & 147 & 150 & 153 & 156 & 159 & 162 & 166 & 172 & 175 & 178 & 181 \\
\hline Core-Section $^{b}$ & $17-1$ & $17-3$ & $17-5$ & $18-1$ & $18-3$ & $18-5$ & $19-1$ & $19-3$ & $19-5$ & $20-1$ & $20-5$ & $21-1$ & $21-3$ & $21-5$ \\
\hline $\begin{array}{l}\text { Bachmannocena apiculata apiculata } \\
\text { B. sp. cf. B. apiculata apiculata (spineless) } \\
\text { B. apiculata monolineata } \\
\text { B. oamaruensis } \\
\text { B. paulschulzii }\end{array}$ & $\begin{array}{r}12 \\
2\end{array}$ & $\begin{array}{r}16 \\
1\end{array}$ & 18 & 2 & 2 & $\begin{array}{l}1 \\
1\end{array}$ & 21 & 22 & 22 & 6 & & $\begin{array}{l}2 \\
4 \\
1 \\
\cdot\end{array}$ & $\begin{array}{l}3 \\
1\end{array}$ & 4 \\
\hline $\begin{array}{l}\text { Corbisema amicula } \\
\text { C. angularis } \\
\text { C. apiculata } \\
\text { C. archangelskiana } \\
\text { C. sp. cf. C. archangelskiana (small) }\end{array}$ & $\begin{array}{l}6 \\
6\end{array}$ & $\begin{array}{r}1 \\
12\end{array}$ & $\begin{array}{l}1 \\
6 \\
1\end{array}$ & $\begin{array}{r}10 \\
2\end{array}$ & 4 & 7 & $\begin{array}{l}1 \\
1\end{array}$ & 7 & & 14 & $\begin{array}{r}1 \\
16\end{array}$ & 2 & 4 & 22 \\
\hline $\begin{array}{l}\text { C. bimucronata bimucronata } \\
\text { C. bimucronata elegans } \\
\text { C. bimucronata rotatoria } \\
\text { C. ellipsis } \\
\text { C. exilis }\end{array}$ & 4 & 6 & $\begin{array}{l}3 \\
1\end{array}$ & $\dot{ }_{2}$ & & & & 2 & 2 & & 2 & 4 & $\begin{array}{l}2 \\
*\end{array}$ & 2 \\
\hline $\begin{array}{l}\text { C. hastata globulata } \\
\text { C. hastata hastata } \\
\text { C. hastata incohata } \\
\text { C. hastata miranda } \\
\text { C. inermis ballantina }\end{array}$ & 6 & $\begin{array}{r}1 \\
11\end{array}$ & $\begin{array}{l}3 \\
1\end{array}$ &.$^{1}$ & $\begin{array}{l}2 \\
2\end{array}$ & ${ }^{*}{ }_{3}$ & $\begin{array}{l}1 \\
2 \\
2\end{array}$ & 2 & 3 & $\begin{array}{l}2 \\
.\end{array}$ & $\dot{*}_{2}$ & 5 & 10 & \\
\hline $\begin{array}{l}\text { C. } \text { sp. } \mathrm{cf} \text {. } C \text {. inermis inermis (spines) } \\
\text { C. jerseyensis } \\
\text { C. katharinae } \\
\text { C. regina } \\
\text { C. regina (bar) }\end{array}$ & 8 & 3 & & 4 & $\begin{array}{r}1 \\
11 \\
9\end{array}$ & 9 & & 1 & $\begin{array}{l}1 \\
5\end{array}$ & 2 & 5 & & $\begin{array}{l}5 \\
5 \\
\end{array}$ & 2 \\
\hline $\begin{array}{l}\text { C. triacantha mediana } \\
\text { C. triacanta triacantha } \\
\text { C. triacanta triacantha (plate) } \\
\text { C. spp. } \\
\text { Dictyocha acuta }\end{array}$ & 8 & $\begin{array}{l}1 \\
6 \\
3\end{array}$ & $\begin{array}{l}8 \\
2\end{array}$ & $\begin{array}{r}4 \\
10 \\
.\end{array}$ & 11 & $\begin{array}{l}1 \\
2 \\
1 \\
4\end{array}$ & $\begin{array}{l}3 \\
2\end{array}$ & $\begin{array}{l}5 \\
1 \\
1 \\
1\end{array}$ & 4 & 12 & 17 & 32 & 11 & 12 \\
\hline $\begin{array}{l}\text { D. aspera s. ampl. } \\
\text { D. byronalis } \\
\text { D. sp. cf. D. byronalis } \\
\text { D. deflandrei completa } \\
\text { D. dickii }\end{array}$ & 2 & $\begin{array}{l}3 \\
7\end{array}$ & 1 & $\begin{array}{l}4 \\
9\end{array}$ & 4 & $\begin{array}{l}4 \\
1\end{array}$ & 7 & 17 & 1 & & & & 1 & 32 \\
\hline $\begin{array}{l}\text { D. hexacantha } \\
\text { D. perlaevis s. ampl. } \\
\text { D. spp. (asperoid) } \\
\text { D. spp. (fibuloid) } \\
\text { Distephanus crux s. ampl. }\end{array}$ & $\begin{array}{l}6 \\
8\end{array}$ & 1 & $\begin{array}{l}2 \\
2\end{array}$ & 1 & $\begin{array}{l}1 \\
2 \\
2 \\
3\end{array}$ & $\begin{array}{l}9 \\
6\end{array}$ & $\begin{array}{l}3 \\
1\end{array}$ & 1 & $\begin{array}{l}1 \\
4 \\
6 \\
*\end{array}$ & $\begin{array}{r}2 \\
28\end{array}$ & $\begin{array}{r}3 \\
16 \\
10 \\
1\end{array}$ & $\begin{array}{r}4 \\
3 \\
10\end{array}$ & $\begin{array}{r}11 \\
3 \\
3\end{array}$ & 8 \\
\hline $\begin{array}{l}\text { D. speculum hemisphaericus } \\
\text { D. speculum triommata } \\
\text { D. spp. (cannopilean) } \\
\text { Macrora barbadensis } \\
\text { M. sp. aff. M. barbadensis }\end{array}$ & & 1 & & & 1 & $\begin{array}{l}1 \\
1\end{array}$ & 1 & 1 & $\begin{array}{l}1 \\
3\end{array}$ & & 1 & 1 & & \\
\hline $\begin{array}{l}\text { M. stella } \\
\text { Naviculopsis biapiculata } \\
\text { N. constricta } \\
\text { N. constricta (semibarred) } \\
\text { N. eobiapiculata }\end{array}$ & $\begin{array}{r}2 \\
30\end{array}$ & $\begin{array}{r}2 \\
23\end{array}$ & $\begin{array}{r}1 \\
4 \\
37 \\
3\end{array}$ & $\begin{array}{r}1 \\
8 \\
39\end{array}$ & $\begin{array}{r}3 \\
6 \\
30\end{array}$ & $\begin{array}{r}1 \\
2 \\
35 \\
2 \\
1\end{array}$ & $\begin{array}{r}2 \\
7 \\
46\end{array}$ & $\begin{array}{r}30 \\
9 \\
\end{array}$ & $\begin{array}{r}4 \\
1 \\
30\end{array}$ & $\begin{array}{r}4 \\
2 \\
16\end{array}$ & $\begin{array}{r}4 \\
18\end{array}$ & $\begin{array}{r}7 \\
1 \\
11 \\
11\end{array}$ & $\begin{array}{r}6 \\
5 \\
22 \\
3 \\
\end{array}$ & $\begin{array}{r}4 \\
10\end{array}$ \\
\hline $\begin{array}{l}N . \text { foliacea } \\
N \text {. trispinosa } \\
N \text {. spp. }\end{array}$ & & 1 & 5 & 3 & 2 & 2 & 1 & & $\begin{array}{l}4 \\
3\end{array}$ & & & 1 & 2 & $\begin{array}{l}2 \\
2\end{array}$ \\
\hline Total specimens & 50 & 100 & 100 & 100 & 100 & 100 & 100 & 100 & 100 & 50 & 100 & 100 & 100 & 50 \\
\hline Corbisema/Naviculopsis ratio & 1.2 & 1.7 & 0.6 & 0.6 & 1.2 & 0.6 & 0.2 & 0.5 & 0.4 & 1.6 & 2.6 & 1.8 & 1.2 & 2.3 \\
\hline
\end{tabular}

Note: * indicates occurrence noted during photography after count completed.

a Zonations are from Okada and Bukry (1980) and Bukry (1981b).

bach section was sampled at the $100-101 \mathrm{~cm}$ level. 
times of silica diagenesis. The lower middle Eocene silicoflagellate-bearing section that was studied in Cores 613-25 to 613-38 belongs to the Dictyocha spinosa Subzone. Coccolith biostratigraphic units in this siliceous coccolith chalk section range from the Discoasteroides keupperi Subzone (CP12a) up to the Chiasmolithus gigas Subzone (CP13b) (Table 3). The Rhabdosphaera inflata Subzone (CP12b) in Cores 613-36 and 613-37 has been rarely reported with silicoflagellates. The assemblages here are dominated by Naviculopsis, but are distinguished from younger assemblages at Site 612 by the presence of older taxa such as Corbisema disymmetrica communis and Dictyocha deflandrei lobata. Fairly low silicoflagellate abundances in some samples, the strongly etched state of diatoms, and the generally low Corbi-
sema/Naviculopsis ratios indicate stronger silica dissolution at Site 613 than at Site 612 .

The oldest assemblages in Cores 613-37 and 613-38 are sparse and are dominated by Naviculopsis ( 65 to $98 \%$ ). Diversity is higher in Cores 613-35 and 613-36, and $N a$ viculopsis is less dominant (42 to $52 \%$ ) as Corbisema doubles in abundance and number of taxa. The top of the range of Corbisema disymmetrica communis, a $\mathrm{Pa}$ leocene and early Eocene taxon (Bukry, 1976a), occurs in middle Eocene Sample 613-35-3, 100-101 cm.

Spined forms of Bachmannocena (Bachmannocena paulschulzii) first occur in middle Eocene Sample 613$31-3,100-101 \mathrm{~cm}$. Bachmannocena is, however, poorly represented at this site. More exhaustive counts of the sparse assemblages in the future may fill in some of these

Table 3. Middle Eocene silicoflagellates from Site 613 (Cores 613-25 to 613-38), recorded as percent, with total specimens, Corbisema/Naviculopsis ratio, and biostratigraphic zonal assignments.

\begin{tabular}{|c|c|c|c|c|c|c|c|c|c|c|c|c|c|c|c|c|}
\hline \multirow{3}{*}{$\begin{array}{l}\frac{\text { Silicoflagellate zone }^{\mathrm{a}}}{\text { Coccolith zone }^{\mathrm{a}}} \\
\text { Sub-bottom depth }(\mathrm{m})\end{array}$} & \multicolumn{16}{|c|}{ Naviculopsis foliacea Zone (Dictyocha spinosa Subzone) } \\
\hline & \multicolumn{3}{|c|}{ CP13b } & \multicolumn{6}{|c|}{ CP13a } & \multirow{2}{*}{\begin{tabular}{|c|}
$\mathrm{CP} 12$ \\
422 \\
\end{tabular}} & \multicolumn{5}{|c|}{ CP12b } & \multirow{2}{*}{$\begin{array}{c}\text { CP12a } \\
441\end{array}$} \\
\hline & 324 & 343 & 362 & 378 & 387 & 397 & 406 & 416 & 419 & & 425 & 428 & 432 & 435 & 438 & \\
\hline Core-Section $^{\mathrm{b}}$ & $25-5$ & $27-5$ & $29-5$ & $31-3$ & $32-3$ & 33-3 & $34-3$ & $35-3$ & $35-5$ & $36-1$ & $36-3$ & $36-5$ & $37-1$ & $37-3$ & $37-5$ & $38-1$ \\
\hline $\begin{array}{l}\text { Bachmannocena apiculata apiculata (no septa) } \\
\text { B. apiculata inflata } \\
\text { B. sp. cf. B. apiculata inflata } \\
\text { B. connudata } \\
\text { B. paulschulzii }\end{array}$ & & & & $\begin{array}{l}6 \\
4 \\
1\end{array}$ & & & & & & & & 1 & & 12 & & \\
\hline $\begin{array}{l}\text { B. venusta } \\
\text { B. sp. cf. } B \text {. venusta } \\
\text { Corbisema angularis } \\
\text { C. apiculata } \\
\text { C. archangelskiana }\end{array}$ & 2 & $\begin{array}{r}10 \\
2\end{array}$ & & 8 & 2 & 2 & $\mathrm{x}$ & $\begin{array}{r}2 \\
12\end{array}$ & 7 & & 2 & 15 & $\begin{array}{l}6 \\
2\end{array}$ & $\begin{array}{r}11 \\
9\end{array}$ & 2 & \\
\hline $\begin{array}{l}\text { C. bimucronata bimucronata } \\
\text { C. bimucronata elegans } \\
\text { C. disymmetrica communis } \\
\text { C. hastata globulata } \\
\text { C. hastata hastata }\end{array}$ & $\begin{array}{l}2 \\
2\end{array}$ & 2 & $\mathrm{x}$ & $\begin{array}{r}13 \\
1\end{array}$ & 4 & 2 & & $\begin{array}{l}2 \\
2\end{array}$ & $\begin{array}{l}1 \\
8 \\
1\end{array}$ & & 4 & 7 & 2 & 4 & $\begin{array}{l}2 \\
2\end{array}$ & \\
\hline $\begin{array}{l}\text { C. hastata hastata (double spines) } \\
\text { C. hastata miranda } \\
\text { C. inermis ballantina } \\
\text { C. inermis inermis } \\
\text { C. } \text { sp. cf. C. } \text { inermis inermis (spines) }\end{array}$ & 22 & & $\begin{array}{l}x \\
x\end{array}$ & 1 & 2 & $\begin{array}{l}1 \\
3\end{array}$ & & 2 & $\begin{array}{l}1 \\
2 \\
4\end{array}$ & & 2 & 1 & & & 6 & \\
\hline $\begin{array}{l}\text { C. katharinae } \\
\text { C. regina } \\
\text { C. toxeuma } \\
\text { C. triacantha triacantha s. ampl. } \\
\text { C. spp. }\end{array}$ & 22 & 2 & $\begin{array}{l}x \\
x\end{array}$ & 12 & & 1 & $\mathrm{x}$ & $\begin{array}{r}2 \\
26 \\
6\end{array}$ & $\begin{array}{l}3 \\
2 \\
1\end{array}$ & & 16 & $\begin{array}{l}1 \\
4\end{array}$ & & & & 2 \\
\hline $\begin{array}{l}\text { Dictyocha brevispina s. ampl. } \\
\text { D. byronalis } \\
\text { D. deflandrei deflandrei } \\
\text { D. deflandrei lobata } \\
\text { D. spinosa }\end{array}$ & 20 & 6 & $\mathrm{x}$ & & 2 & $\begin{array}{l}3 \\
3\end{array}$ & $\mathrm{x}$ & & $\begin{array}{r}10 \\
6\end{array}$ & & $\begin{array}{r}4 \\
12\end{array}$ & $\begin{array}{r}6 \\
17 \\
1\end{array}$ & * & & 6 & \\
\hline $\begin{array}{l}\text { D. spp. (asperoid) } \\
\text { Distephanus sp. cf. D. quinquangellus } \\
\text { D. spp. (cruxoid) } \\
\text { Naviculopsis biapiculata } \\
\text { N. constricta }\end{array}$ & 2 & 46 & $\mathrm{x}$ & $\begin{array}{l}1 \\
5\end{array}$ & $\begin{array}{r}2 \\
32\end{array}$ & 20 & $\mathrm{x}$ & $\begin{array}{r}4 \\
24\end{array}$ & $\begin{array}{r}2 \\
31\end{array}$ & & $\begin{array}{r}6 \\
16\end{array}$ & 10 & $\begin{array}{l}4 \\
2\end{array}$ & 11 & 34 & 20 \\
\hline $\begin{array}{l}\text { N. eobiapiculata } \\
\text { N. foliacea } \\
\text { N. nordica nordica } \\
\text { N. punctilia punctilia } \\
\text { N. spp. }\end{array}$ & $\begin{array}{r}2 \\
26\end{array}$ & $\begin{array}{r}4 \\
18 \\
2\end{array}$ & $\stackrel{x}{X}$ & 40 & $\begin{array}{r}4 \\
50\end{array}$ & 54 & (X) & 18 & 21 & & $\begin{array}{r}18 \\
12 \\
2 \\
2\end{array}$ & 34 & 26 & 54 & $\begin{array}{r}4 \\
36\end{array}$ & $\begin{array}{l}14 \\
64\end{array}$ \\
\hline Total specimens & 50 & so & 34 & 100 & 50 & 100 & 33 & 50 & 100 & 0 & 50 & 100 & 50 & 57 & 50 & 50 \\
\hline Corbisema/Naviculopsis ratio & 1.8 & 0.26 & - & 0.96 & 0.09 & 0.18 & - & 1.3 & 0.58 & - & 0.56 & 0.66 & 0.05 & 0.06 & 0.14 & 0.02 \\
\hline
\end{tabular}

Note: $\mathrm{X}=$ species occurrences for assemblages too sparse for meaningful percents; $\mathrm{X}=$ predominant species in sparse assemblages. $\bullet$ indicates occurrence noted after count completed.

a Zonations are from Okada and Bukry (1980) and Bukry (1981b).

b Each section was sampled at the $100-101 \mathrm{~cm}$ level. 
ranges. For the moment, the presence of Bachmannocena apiculata inflata (Core 613-31) above the range of C. disymmetrica communis (Core 613-35) reflects the relation observed in DSDP Core 385-4 from the New England Seamount Chain (Bukry, 1978c). The correlation is also supported by association of the specialized taxa Corbisema bimucronata elegans and $C$. hastata hastata (paired spines) at both sites. Similarities in the Dictyocha spinosa Subzone silicoflagellate arrays at DSDP Sites 385,386 , and 613 indicate a rather uniform planktonic regime through the western North Atlantic Ocean.

A distinctive Eocene diatom with a large central areola, illustrated previously on the basis of western North Atlantic specimens (Bukry, 1978a, b), was found to occur in a similar stratigraphic interval at Site 613. Coscinodiscus eomonoculus ranges from Sample 613-38-1, 100$101 \mathrm{~cm}$ to Sample 613-31-3, 100-101 cm, within the Dictyocha spinosa Subzone of silicoflagellates. The combined occurrences of $C$. eomonoculus at DSDP Holes $385,390 \mathrm{~A}$, and 613 span the lower Eocene to middle Eocene boundary.

\section{BIOSTRATIGRAPHIC ZONATION}

The middle and upper Eocene silicoflagellates at Sites 612 and 613 (Tables 1, 2, and 3) may be assigned to three low-latitude zones using the total range of Dictyocha hexacantha from coccolith Subzone CP14a to Subzone CP15b. The lower interval in Cores 613-25 to 61338 and $612-25$ to $612-33$ is in the Dictyocha spinosa Subzone of the Naviculopsis foliacea Zone. Besides the presence of the two name-giving taxa, the tops of the ranges of Corbisema disymmetrica communis and Dictyocha deflandrei lobata are also noted here. This relation confirms the similar western Atlantic ranges that were determined for DSDP Leg 43 in the same region (Bukry, 1978c). The first occurrences for Corbisema bimucronata bimucronata and $C$. regina in the zone are sporadic, possibly as a result of the small abundances and low counts for silicoflagellates at Site 613. Even though only low counts were achieved on the sparse Site 613 material, the silicoflagellates of this early middle Eocene age ( $=$ coccolith Subzones CP12a to CP13b) have rarely been studied before.

The Dictyocha hexacantha Zone at Site 612 is well characterized by the total range of $D$. hexacantha in Cores $612-19$ to $612-25$. This interval begins in upper middle Eocene coccolith Subzone CP14a and ends in upper Eocene Subzone CP15b. The overlapping ranges of Bachmannocena oamaruensis and Macrora najae at Site 612 also form a useful correlation set, because they have previously been identified together in the Kellogg Shale of California (Barron et al., 1984), DSDP Core 356-6 from the Rio Grande Rise (Bukry, 1977), and DSDP Core 386-14 from the Bermuda Rise (Bukry, 1978c). All four joint occurrences are within the $D$. hexacantha Zone and coccolith Subzone CP14a. The unconformity in the base of Core 612-21, identified here by silicoflagellates, divides the zone into two taxonomically distinctive intervals. The upper part has common Corbisema apiculata, $C$. triacantha mediana, and $N$. constricta, but Macrora barbadensis and Naviculopsis foliacea are much reduced from the abundances below the unconformity. $M$. barbadensis is predominant in the lower interval, which is also characterized by common Corbisema regina, Dictyocha byronalis, and $N$. foliacea.

Recently, Shaw and Ciesielski (1983) found major problems with using Dictyocha hexacantha for biostratigraphy on the Falkland Plateau, and recommended against using it as a zonal indicator when other more suitable species could be used. Because they also report no $\mathrm{Ma}$ crora najae and only sparse $N$. foliacea, the Falkland assemblages represent an unusual environment relative to the other more northerly sites in the Atlantic Ocean. The Falkland assemblages, with their specialized guide fossils, appear to have been deposited in partial ecologic isolation, since their new Eocene zonal markers do not occur at Site 356, off Brazil, or at Site 612, off New Jersey.

The lower Corbisema apiculata Zone is identified above the range of Dictyocha hexacantha in Cores 612-17 to 612-19 by the co-occurrence of Corbisema apiculata, $C$. bimucronata s. ampl., C. triacantha mediana, N. biapiculata, and $N$. constricta. These taxa are also prominent in the $C$. apiculata Zone at DSDP Hole 369A, off northwest Africa (Bukry, 1978a). The two assemblages differ in the earlier abundant occurrences of Bachmannocena apiculata apiculata and Macrora stella at Site 612. B. apiculata apiculata, however, becomes common near the end of the range of $D$. hexacantha in the upper middle or upper Eocene in California (Dumoulin, 1984), south of Tasmania (Perch-Nielsen, 1975), and probably on the Falkland Plateau (Shaw and Ciesielski, 1983). The later high abundances of 17 to $54 \%$ at Hole $369 \mathrm{~A} \mathrm{oc}-$ curred just after the Braarudosphaera chalk beds accumulated in the South Atlantic in the late Oligocene, and reflect local paleoceanographic conditions at that site.

The youngest Eocene silicoflagellates studied from Site 612, in Sample 612-17-1, 100-101 cm, are upper upper Eocene on the basis of the associated coccolith assemblage which contains the upper upper Eocene co-occurrence of Isthmolithus recurvus and Discoaster saipanensis. The next higher silicoflagellates, from Core 612-16, are Miocene, suggesting a significant stratigraphic unconformity (see Poag and Low, this volume).

\section{RELATIVE PALEOTEMPERATURES}

Because most Paleogene silicoflagellate assemblages are dominated by genera which subsequently became extinct (Bachmannocena at $0.8 \mathrm{Ma}$, Corbisema at $13 \mathrm{Ma}$, Naviculopsis at $15 \mathrm{Ma}$ ), relative paleotemperature systems based on paleogeographic assortment of taxa have been proposed (Ciesielski, 1975; Dumoulin, 1979, 1984; Barron et al., 1984). Neogene systems are largely based on the geographic distributions of living genera Dictyocha and Distephanus (Gemeinhardt, 1934).

That most biosiliceous sections represent brief durations, and that few comparisons are available for different latitudes to establish Paleogene paleogeographic distribution and abundances, have posed serious hindrances to paleotemperature analysis, which are slowly being remedied by DSDP and Ocean Drilling Project (ODP) oceanic coring. Quantitative studies of high-latitude Eocene 
silicoflagellate assemblages from the Falkland Plateau, recently published by Shaw and Ciesielski (1983), provide new contrast to the mid-latitude assemblages of the Kellogg Shale (Barron et al., 1984), the Rio Grande Rise (Bukry, 1977), and Leg 95 Sites 612 and 613. Paleomagnetic/biostratigraphic correlations among these sites show that, in the upper middle Eocene of Cores 512-6 to 51219 from the Falkland Plateau, Naviculopsis completely dominates Corbisema, so that $\mathrm{C} / \mathrm{N}$ ratios are extremely low $(0.02$ to 0.30$)$. $\mathrm{C} / \mathrm{N}$ values for the coeval intervals at Sites 612 and 356 and in the Kellogg Shale are typically 10 to 50 times higher. Because of perceived biogeographic assortment between Corbisema and Naviculopsis, higher values may signify warmer conditions. The $\mathrm{C} / \mathrm{N}$ values for Leg 95 range up to 6.3 (Tables 1, 2, and 3).

At the species level, the approximate equivalent of the CP14a Subzone on the Falkland Plateau, in Cores 512-6 to 512-10 (magnetic Anomaly 18; Shaw and Ciesielski, 1983), has Naviculopsis biapiculata and N. constricta completely dominant over $\mathrm{N}$. foliacea, and $\mathrm{Ma}$ crora barbadensis is missing. This indicates a completely different paleoecologic province from that of Leg 95, and, by biogeography, a colder one. Analysis of the $\mathrm{C} / \mathrm{N}$ ratio and the distribution of $N$. constricta and $M$. barbadensis at the mid-latitude sites suggests that the ratio and the species could be useful for determining late middle Eocene paleotemperature trends.

A comparison within the CP14a equivalents shows that $\mathrm{C} / \mathrm{N}$ values for warm-temperate Site 356 in the South Atlantic (lat. $28^{\circ} \mathrm{S}$ ) range from 1.1 to 1.8 , whereas farther south, in the cooler province at Site 512 (lat. $50^{\circ} \mathrm{S}$ ), coeval $\mathrm{C} / \mathrm{N}$ values range from only 0.02 to 0.07 . The current studies at Site 612 (lat. $39^{\circ} \mathrm{N}$ ) off New Jersey yield $\mathrm{C} / \mathrm{N}$ values of 0.2 to 0.9 . At Site 612 the maximum values for warmth-favoring $M$. barbadensis coincide with the peak values for the $\mathrm{C} / \mathrm{N}$ ratio in Samples 612-22-3, $100-101 \mathrm{~cm}, 612-23-3,100-101 \mathrm{~cm}$, and 612-25-1, 100$101 \mathrm{~cm}$ (Table 1). There is no coincident diminishment in the proportion of $N$. constricta to $N$. foliacea over other samples in the section, so paleotemperature changes being measured were too minor to activate any threshold relation that would change the abundance relation between these Naviculopsis species.

Difficulties with using the $\mathrm{C} / \mathrm{N}$ ratio as a paleoenvironmental indicator can be seen in the upper Eocene of Site 612, representing a time of global cooling (Kennett, 1977). Although cool-indicator $N$. constricta completely surpassed $N$. foliacea in abundance, the $\mathrm{C} / \mathrm{N}$ values are higher (warmer) than for the upper middle Eocene. Another potential problem for the $\mathrm{C} / \mathrm{N}$ ratio is differential solution between the two genera. For example, data from the lower middle Eocene of Site 613 show very low to moderate $\mathrm{C} / \mathrm{N}$ values of 0.02 to 1.8 . The 0.02 values would seemingly predict conditions as cold as those of Site 512 on the Falkland Plateau, but in each sample with the coldest values the effects of dissolution are strongest and the total silicoflagellate abundances are low. Corbisema may appear to be much sparser than Naviculopsis, because of differential dissolution. Therefore, dissolution effects, whether detected or not, would limit the precision of the $\mathrm{C} / \mathrm{N}$ ratio in gauging relative paleotemperature. The ratio may serve as a general guide as better paleotemperature measures are sought.

Although appealingly simple, the genus-ratio approach to paleotemperature in the Paleogene should probably be replaced by analysis of individual species distribution. For example, an increase in the abundances of $\mathrm{Na}$ viculopsis biapiculata and $N$. eobiapiculata in the presumably cool late Eocene represented by Leg 95 Cores 612-17 to 612-21 contrasts with their near absence from middle Eocene Cores 612-22 to 612-33. At Falkland Site $512, N$. biapiculata (including N. eobiapiculata) is a codominant with $N$. constricta in the middle Eocene, and should thus provide a guide to cooler-water assemblages at lower latitudes. But care should be taken to note that the high abundances ( 15 to $36 \%$ ) of $N$. biapiculata and $N$. eobiapiculata at Site 512 are not duplicated at any of the other coeval high-latitude sections (Fig. 1). Abundances are 1 to $3 \%$ at Site 283 (lat. $44^{\circ} \mathrm{S}$ ), $0 \%$ at Sites 399 (lat. $67^{\circ} \mathrm{N}$ ) and 340 (lat. $67^{\circ} \mathrm{N}$ ), and only $1 \%$ at Site 356 (lat. $28^{\circ} \mathrm{S}$ ). Although Site 512 is the most complete and best-documented site for high-latitude silicoflagellates, it is also paleoecologically unique and difficult to relate to the Australian (Site 283) and Norwegian (Sites 339 and 340) areas because of the unusual array of species. Results from areas other than the Falkland Plateau will need to be used to establish cosmopolitan effects on Eocene silicoflagellate assemblages, but at present these areas are represented by less complete stratigraphic sections. Seemingly, the species distributions of the genus Naviculopsis could be good guides to Paleogene paleotemperatures because of the diversity and flux in abundances observed at most sites. Further speculation about paleotemperature trends that is based on silicoflagellates in the Dictyocha hexacantha Zone and equivalents will require more data. For example, the lack of a systematic abundance change of Dictyocha hexacantha with latitude, in data tabulated from different sites, should be considered (Table 4).

\begin{tabular}{|c|c|c|}
\hline Site & Latitude & D. hexacantha $\%$ \\
\hline \multicolumn{3}{|l|}{ Atlantic } \\
\hline 340 & $67^{\circ} \mathrm{N}$ & 2 \\
\hline 339 & $67^{\circ} \mathrm{N}$ & $2-5$ \\
\hline 406 & $56^{\circ} \mathrm{N}$ & $7-31$ \\
\hline 612 & $40^{\circ} \mathrm{N}$ & $1-11$ \\
\hline 386 & $31^{\circ} \mathrm{N}$ & 1 \\
\hline 356 & $28^{\circ} \mathrm{S}$ & $2-3$ \\
\hline 512 & $50^{\circ} \mathrm{S}$ & 2 \\
\hline \multicolumn{3}{|l|}{ Pacific } \\
\hline California & $36^{\circ} \mathrm{N}$ & 40 \\
\hline Peru & $14^{\circ} \mathrm{S}$ & 13 \\
\hline 206 & $32^{\circ} \mathrm{S}$ & 16 \\
\hline 283 & $44^{\circ} \mathrm{S}$ & $1-23$ \\
\hline
\end{tabular}




\section{OBSERVATIONS AND SPECULATIONS REGARDING POSSIBLE EVOLUTIONARY LINEAGES OF EOCENE SILICOFLAGELLATES}

The sequence of silicoflagellate assemblages at Sites 612 and 613 spans the middle and upper Eocene from coccolith Subzone CP12a to Subzone CP15b, and represents an interval of about 9 m.y. (Okada and Bukry, 1980). Subzones CP14b and CP15a are essentially absent from the section, and this absence represents a break in the stratigraphic record of up to 3 m.y.

During the 9-m.y. depositional period involved, several fundamental changes in silicoflagellate skeletal structure and abundances occurred:

1. In genus Bachmannocena, which had been a minor sporadic genus with only unspined species in the lower cores, several new species with spines appeared and one, B. apiculata apiculata, became numerically significant (up to $22 \%$ ) in the upper cores.

2. Symmetry, which was mainly radial and bilateral for species of Corbisema in the lower cores, became notably less regular in the upper cores with the appearances of Corbisema bimucronata rotatoria, C. exilis, $C$. hastata incohata, and C. katharinae. Another change in symmetry was the rotation of strut-ring junctions to uncentered location, as in C. triacantha mediana in the upper cores. Similar structural rotation appeared in other genera.

3. In genus Dictyocha, both $D$. acuta and D. byronalis developed the rotation character in this interval.

4. Among Distephanus species, quadrate and pentagonal specimens occurred in the lower cores before hexagonal specimens appeared.

5. In the incertae sedis genus Macrora, transitional specimens that are structurally intermediate between the two major species occurred near the beginning of the range of the younger of the two species. This could suggest rapid evolution linking the two species, except that the transitional forms were observed just above the major unconformity.

6. Among Naviculopsis, several structural styles of dominant $N$. foliacea occurred.

In addition to these general trends, more detailed changes were observed at the species level.

The two species Bachmannocena apiculata apiculata and $B$. oamaruensis are both triangular and their principal ranges are basically consecutive, although they overlap slightly in Core 612-21. Evolutionary connection is implied by this biostratigraphy at Site 612 , and the implication is confirmed by the occurrence of transitional specimens only within the same core (Core 612-21). These specimens (Plate 1, Fig. 2) have the spineless character of older $B$. oamaruensis and the septate character of younger $B$. apiculata apiculata.

Bachmannocena apiculata monolineata appeared at the top of the Eocene section (Core 612-17) after the $B$. apiculata apiculata population was already well established. This new isosceles triangle-shaped subspecies is similar in form to later B. apiculata curvata of the late Oligocene and Miocene. The change from convex or straight sides to concave sides for successful Bachman- nocena populations apparently did not occur until after the Eocene. For example, see B. schulzii and B. apiculata curvata, both in the Oligocene (Martini and Müller, 1976; Bukry, 1976b, 1978a).

At Site 612 , Bachmannocena venusta occurs in many samples at low abundances ( 1 to $3 \%$ ) in the interval from Core 612-22 to Core 612-27. Correlation with other sites in California and the North and South Atlantic oceans suggests that this interval corresponds to the principal range of the main stratigraphic population. But in lower middle Eocene Core 613-37 there appear to be $B$. venusta specimens associated with $B$. connudata and transitional forms tabulated as $B$. sp. cf. $B$. venusta. These spineless taxa are characterized by ring forms resembling a rhomb with rounded corners ( $B$. venusta), an ellipsoid with more acute ends ( $B$. connudata), and a composite intermediate that has one long side like the oblique angle from $B$. venusta and one long side with a continuous curve like $B$. connudata (see Plate 2, Fig. 5). This could represent a moment in an evolutionary transition from $B$. connudata to $B$. venusta, and not just a phenotypic variation, because the younger populations of $B$. venus$t a$ at Site 612 are not associated with any transitional or $B$. connudata s. str. specimens. The record of the implied transition may occur in or below Core 612-26, but the present initial study indicates a scarcity of Bachmannocena to test this hypothesis at Sites 612 and 613. More detailed study to establish the record of Bachmannocena at these sites will be needed.

A final possible evolutionary transitional form of Bachmannocena is a rounded and asymmetrically triangular specimen from Sample 612-24-5, 100-101 cm, which has been tabulated as $B$. sp. cf. $B$. venusta (Plate 3, Fig. 1). This could be a transitional form between older $B$. venusta and younger $B$. oamaruensis, which first occurs just above, in Sample 612-24-1, 100-101 cm. Whereas the form of this specimen resembles that of the B. connudat $a$-to- $B$. venusta transitional specimens in deeper cores, the size and biostratigraphy better match $B$. oamaruensis.

Among Corbisema species, the biostratigraphy at Sites 612 and 613 implies that $C$. jerseyensis evolved from $C$. hastata globulata in the lower Dictyocha hexacantha Zone through size reduction and narrowed isosceles outline. Similarly, a minor species in the $C$. hastata plexus, $C$. hastata miranda, with a long Eocene range, was the apparent source of the late Eocene populations of $C$. hastata incohata, a species with pronounced asymmetry in several structural elements (see Systematics).

Aside from the appearance or disappearance of Dictyocha deflandrei lobata and $D$. hexacantha within the studied section, the main evolutionary observations concern asperoid $D$. spp. and $D$. byronalis. Dictyocha byronalis occurs through most of the middle and upper Eocene section, but at the upper end of the range there is a diminishment of the characteristic sculptured shape of the ring and it approaches a more regular rhomboid from (D. sp. cf. D. byronalis). This effect is also seen in the increase in other more regular rhomboid taxa of Dictyocha (Table 2). Future analysis of the details of these morphologic changes, which reversed the previously re- 
duced state of Dictyocha in the early middle Eocene, may help to reveal early Dictyocha evolution.

Large Dictyocha specimens resembling the Neogene taxa $D$. aspera and $D$. brevispina appeared and disappeared from the sections at Sites 612 and 613 without any clear transitional forms. Ecological controls may determine the sporadic occurrence pattern of these taxa through the Cenozoic.

A biostratigraphic surprise of Leg 95 phytoplanktic assemblages is the presence of incertae sedis species $\mathrm{Ma}$ crora stella in the Eocene. It occurs fairly consistently (1 to $7 \%$ ) in Cores $612-17$ to $612-21$, above the major unconformity at the middle Eocene to upper Eocene boundary. Previously, M. stella had been reported only as old as Oligocene (Bukry, 1978a). In the lower part of its new range at Site 612, there are specimens transitional to $M$. barbadensis, the main Eocene species. These transitional specimens, tabulated as $M$. sp. aff. $M$. barbadensis, have peripheries intermediate between smooth $M$. barbadensis and serrate $M$. stella (Plate 7, Figs. 2 and 3). Doming of the central portion is also intermediate. Both $M$. stella and the intermediate form are missing below the unconformity. Large populations of $M$. barbadensis characterize the lower $D$. hexacantha Zone at several locations, but transitions to $M$. stella have not been found. The proximity of the intermediate specimens to the unconformity at Site 612 suggests that this transition occurred sometime corresponding to the middle or upper $D$. hexacantha Zone.

\section{SYSTEMATIC PALEONTOLOGY OF NEW TAXA AND NEW COMBINATIONS}

Silicoflagellates

\section{Genus BACHMANNOCENA Locker, 1974 emend. Bukry}

Remarks. The original genus Bachmannocena was limited to ring silicoflagellates with two or more spines. That restriction is herein removed and emended to include all natural ring silicoflagellates that lack apical structures, whether or not they have spines. Mesocena has been the most widely used generic name for such ring silicoflagellates, but Locker's (1974) restudy of the Ehrenberg type materials led him to recognize that the designated type species of Mesocena is more closely related to the Distephanus-like genus Octactis. Thus, monospecific Octactis pulchra Schiller is effectively a junior synonym of Mesocena? octogona, and by comparison so is M.? heptagona, which can be considered conspecific. Stratigraphically, Locker (1974) noted that the type material for M.? octogona and M.? heptagona was Recent and from near Callao, Peru. Octactis pulchra ranged from late Pliocene to Recent. The actual ring silicoflagellates became extinct in the late Pliocene to mid-Pleistocene.

The size, symmetry, apical structure, and basal pikes of Octactis pulchra are a good match for M.? octogona and M.? heptagona. Because the latter are the only species ascribed to Mesocena in the original paper where that genus was established, Loeblich et al. (1968) selected M. ? octogona as the type of Mesocena. Later, Dumitricá (1973) recommended changing the type species of genus Paradictyocha Frenguelli, 1940 from the original Distephanus polyactis (Ehrenberg) to Mesocena circulus var. apiculata Lemmermann, because of Dumitrică's evolutionary theory about the derivation of different mesocenid specimens. Dumitrică also recommended against using as types the only two species of Mesocena listed and illustrated in the original publication on Mesocena, in order to avoid useless troubles. Instead, Dumitrică selected $M$. elliptica Ehrenberg $(1844$, pp. 71,84$)$, as designated by Frenguelli (1940). But Dictyocha circulus Ehrenberg (1844, p. 65) had page priority. Therefore, the selection of $M$. elliptica was a ter- tiary choice for a legal type. The interpretation of Loeblich et al. seems logical and, according to the most direct application of the rules of priority, seems reasonable.

Locker (1974) recommended retaining genus Mesocena through a subsequent designation of $M$. elliptica as a type species (Frenguelli, 1940; see also Deflandre, 1932). He cited several IRZN articles to support this proposal, but the present biological consensus is that silicoflagellates are chrysophyte algae (Van Valkenburg, 1980) and thus subject to the International Code of Botanical Nomenclature (ICBN). Also, Mesocena of Locker would satisfy Locker's definition of Bachmannocena in general form and spines. The genus Bachmannocena Locker, 1974 , with $B$. diodon (Ehrenberg) as the type species, is accepted as the first practically and procedurally correct taxon for ring silicoflagellates. Conservation of the widely used name Mesocena could be considered, because Ehrenberg's misinterpreted description involves a ring with no apical structure, and because the subsequent designation of $M$.? octogona as the type was based on a misinterpretation of the construction of that species. An argument for retention of Mesocena as a name for ring silicoflagellates could be ICBN Article 41 (Lanjouw et al., 1966), which says that valid publication of a genus requires only the name and a description. Ehrenberg (1843) apparently fulfilled that article without designating a type species. All of the subsequent uncertainty over the status of the name has involved different attempts at typification, which may not have been required (Deflandre, 1932; Frenguelli, 1940; Loeblich et al., 1968; and Dumitricà, 1973). Certainly in the case of Mesocena and its discovered connection with Octactis by Locker, note 4f. of the ICBN Guide for the Determination of Types, on misinterpretation, could be applied here. In any event, use of emended Bachmannocena is accepted here as an unambiguous means to deal with the ring group. Historically, Mesocena has been a minor silicoflagellate genus; Loeblich et al. (1968) recorded only 46 valid names in the genus. About 20 additional taxa have been added from 1968 to 1985. Because of the manageably small number of taxa involved (smaller still when synonyms are identified), conservation of the name Mesocena for use with ring silicoflagellates is not a practical necessity.

For use in this report, genus Bachmannocena Locker, 1974 emended, is applied to simple ring silicoflagellates, with and without spines. The original ascribed species of genus Mesocena Ehrenberg 1843 dictate that that genus is the senior synonym of genus Octactis Schiller, 1925 and is presently monospecific: $M$. octogona $=O$. pulchra. Genus Paradictyocha Frenguelli, 1940 can be related to Distephanus through the structure of its type species Distephanus polyactis Ehrenberg. Genus Septamesocena Bachmann, 1970 could be considered a special case of Bachmannocena.

An aside to this opinion on genera is the recent paper by Ling and Takahashi (1985), which argues that genus Octactis should be considered a junior synonym of genus Distephanus. Because Locker (1974) showed that the type of Octactis is synonymous with the type of Mesocena, then, if the Ling and Takahashi proposal were to be accepted, Mesocena would become the senior synonym for Distephanus. This position need not be accepted, because there are sufficient structural distinctions to maintain Mesocena $(=$ Octactis) as a genus separate from Distephanus.

To facilitate the use of Bachmannocena, the main geologically useful taxa of ring silicoflagellates are transferred herein.

Bachmannocena apiculata apiculata (Schulz) n. comb. (Plate 1, Fig. 1)

Mesocena oamaruensis var. apiculata Schulz, 1928, p. 240, fig. 11. Mesocena apiculata (Schulz) Deflandre, 1932, p. 499, figs. 34, 35. Septamesocena apiculata (Schulz) Bachmann, 1970, p. 13.

Remarks. If oblique spine orientation were established as a consistent character, then use of Septamesocena as genus or subgenus could be adopted. But the presence of inner septae at the corners is variable (Dumitrică, 1973).

Bachmannocena apiculata curvata (Bukry) n. comb.

Mesocena apiculata curvata Bukry, 1976b, p. 849. pl. 2, figs. 15, 16.

Bachmannocena apiculata evexa (Bukry) n. comb.

Mesocena apiculata evexa Bukry, 1984 [1985], p. 558, pl. 2, figs. 9-11; pl. 3. figs. 1-5. 
Bachmannocena apiculata glabra (Schulz) n. comb.

Mesocena polymorpha var. triangula Lemmermann fa. glabra Schulz, 1928 , p. 237, fig. ?3b, 3c.

Mesocena apiculata glabra (Schulz) Bukry, 1978a, p. 698, pl. 2, figs. $14,15$.

Bachmannocena apiculata inflata (Bukry) n. comb. (Plate 1, Fig. 3)

Mesocena apiculata inflata Bukry, 1978c, p. 786, pl. 3, figs. 1-3. Mesocena pseudoapiculata Martini, 1981, p. 281, pl. 1, fig. 10.

Bachmannocena apiculata monolineata Bukry, n. subsp. (Plate 1, Fig. 4)

Mesocena polymorpha var. triangula (E.) L., Schulz, 1928 (in part), p. 237 , fig. $3 \mathrm{~b}$.

?Mesocena aff. apiculata (Schulz) Deflandre, Glezer, 1966, p. 303, pl. 28 , fig. 5 . (Odd spine orientation.)

Mesocena apiculata (Schulz) Deflandre, Bachmann, 1970 (in part), p. 280 , pl. 5, fig. 10.

Mesocena apiculata Schulz, Martini and Müller, 1976 (in part), p. 872, pl. 11 , fig. 2 only.

Description. Bachmannocena apiculata monolineata has an isosceles triangular ring with two long coequal convex sides and one short straight side. There are short spines at the corners.

Remarks. Bachmannocena apiculata lineata is distinguished from $B$. apiculata apiculata by the isosceles shape of the ring, with two convex sides and one straight side. It is distinguished from isosceles $B$. apiculata curvata by having a straight short side that is not concave.

Occurrence. Bachmannocena apiculata monolineata is sparse (1 to $2 \%$ ) at Site 612, occurring only in the uppermost Eocene of Core 61217. It occurs there in conjunction with $B$. apiculata apiculata, not $B$. apiculata curvata. Therefore, it may help to identify the top of the Eocene. Bachmann (1970) showed it occurring in the Oligocene. A Paleocene specimen shown by Glezer (1966) may not be directly related, because the basal spines are directed downward and the age predates that of Bachmannocena elsewhere in the world. Bachmannocena apiculata monolineata is probably not older than late Eocene (see Tables 1,2 , and 3).

Size. Maximum internal diameter $41 \mu \mathrm{m}$.

Holotype. USNM 401463 (Plate 1, Fig. 4).

Type locality. Western North Atlantic Ocean, DSDP Sample 612-17$3,100-101 \mathrm{~cm}$.

\section{Bachmannocena bispicata (Ciesielski in Shaw and Ciesielski) $\mathbf{n}$.} comb.

Mesocena bispicata Ciesielski in Shaw and Ciesielski, 1983, p. 714, pl. 20 , figs. 3, 6-8.

Bachmannocena circulus var. apiculata (Lemmermann) n. comb.

Mesocena circulus var. apiculata Lemmermann, 1901, p. 257, pl. 10, figs. 9,10 .

Bachmannocena concava (Perch-Nielsen) n. comb.

Mesocena concava Perch-Nielsen, 1976, p. 35, figs. 11, 24.

Remarks. The original samples for Bachmannocena concava may be Oligocene, instead of upper Eocene, because their suggested correlation with the Kellogg Shale or Sidney Shale is not well supported.

Bachmannocena connudata (Bukry) n. comb.

$$
\text { (Plate 1, Fig. 5) }
$$

Mesocena? connudata Bukry, 1978c, p. 786, pl. 3, figs. 4, 5 .

Bachmannocena diodon borderlandensis (Bukry) n. comb.

Mesocena diodon borderlandensis Bukry, 1981b, p. 547, pl. 4, figs. 59 ; pl. 5, figs. $1,2$.

Bachmannocena diodon nodosa (Bukry) n. comb.

Mesocena diodon nodosa Bukry, 1978b, p. 818, pl. 5, figs. 14, 15; pl. 6, figs. 1-5.
Bachmannocena dumitricae (Perch-Nielsen) n. comb.

Paradictyocha dumitricae Perch-Nielsen, 1975, p. 689, pl. 11, figs. 1, 5-8.

Mesocena dumitricae (Perch-Nielsen) emend. Bukry, 1986, pl. 5, figs. 1,2 .

Bachmannocena elliptica (Ehrenberg) n. comb.

Dictyocha (Mesocena) elliptica Ehrenberg, 1840, p. 208. Mesocena elliptica (Ehrenberg) Ehrenberg, 1844, p. 71, 84.

Bachmannocena elliptica var. rhomboidea (Bukry) n. comb.

Mesocena elliptica (Ehrenberg) Ehrenberg var. rhomboidea Bukry, 1985 , pl. 5, figs. 1-6.

Bachmannocena hexalitha (Bukry) n. comb.

Mesocena hexalitha Bukry, 1981b, p. 547, pl. 5, figs. 5-10.

Bachmannocena muticata (Glezer) n. comb.

Mesocena muticata Glezer, 1964, p. 58, pl. 2, fig. 11.

Bachmannocena oamaruensis (Schulz) n. comb.

(Plate 1, Fig. 6; Plate 2, Fig. 1)

Mesocena oamaruensis Schulz, 1928, p. 240, figs. 10a, b.

Remarks. Triangular and rounded triangular rings that lack spines or septae are typically assigned to Bachmannocena oamaruensis. The specimens from Leg 95 are triangular with rounded corners. This species is generally reported as occurring in the middle Eocene to lower Oligocene.

Bachmannocena ovata (Bukry) n. comb.

Mesocena ovata Bukry, 1978c, p. 786, pl. 3 fig. 6 .

Bachmannocena pappii (Bachmann) n. comb.

Mesocena pappii Bachmann, 1962, p. 380, pl. 1, figs. 1-9.

Bachmannocena paulschulzii Bukry, n. nom.

Mesocena oamaruensis var. quadrangula Schulz, 1928, p. 240, fig. 12 (not fig. 13).

Mesocena oamaruensis quadrangula Schulz, Bukry, 1975b, p. 870, pl. 6 , fig. 4.

Mesocena occidentalis Hanna ex Bukry, 1977, p. 832.

Remarks. At the same time that Schulz (1928) described Bachmannocena oamaruensis (Schulz) on the basis of spineless triangular specimens, he also named Bachmannocena oamaruensis var. quadrangula (Schulz) on the basis of a spined quadrate specimen (his fig. 12). He also illustrated a specimen called Bachmannocena oamaruensis $\mathrm{cf}$. quadrangula (Schulz, fig. 13), which differed from the primary specimen by the absence of long spines, the presence of septae at the corners, and by concave sides. In citing this taxon, Loeblich et al. (1968, pp. 55,129 , and 258) eliminated the cf. attribution of figure 13. On the basis of that citation, which indicated coequal status, I inadvertently proposed designating figure 13 as the lectotype of Bachmannocena oamaruensis var. quadrangula (Schulz) (Bukry, 1977). But from Schulz's (1928) original cf. attribution and his description of $20-\mu \mathrm{m}$-long spines, it is now apparent that figure 13 must be rejected and figure 12 used as the lectotype. Acceptance of this concept for B. oamaruensis var. quadrangula means that Mesocena occidentalis Hanna ex Bukry is a junior synonym.

With the type concept of Schulz (1928, fig. 12) established for the name Mesocena oamaruensis var. quadrangula, a new consideration arises. This taxon is not considered to be closely enough related to triangular, spineless $B$. oamaruensis that it can be retained as a variety within that species. Instead, it should be elevated to species status. However, the name quadrangula, at species level, is preoccupied among ring silicoflagellates by Bachmannocena quadrangula (Ehrenberg ex Haeckel, 1887). Therefore, the new name Bachmannocena paulschulzii is proposed, herein, to substitute for Schulz's original name. 
Bachmannocena polyactis (Tsumura) n. comb.

Mesocena polyactis (Deflandre) [sic] Tsumura, 1963, p. 42, fig. 4, pl. 14 , fig. 1.

Bachmannocena quadrangula (Ehrenberg ex Haeckel) n. comb.

Mesocena quadrangula Ehrenberg ex Haeckel, 1887, p. 1556. Figured by Lemmermann, 1901, pl. 10, figs. 5-7, fide Loeblich et al. (1968).

Bachmannocena schulzii (Martini and Müller) n. comb.

Mesocena oamaruensis cf. quadrangula Schulz, 1928, p. 240, fig. 13. Mesocena schulzii Martini and Müller, 1976, p. 873, pl. 11, figs. 3, 13.

Remarks. By stratigraphy and morphology, B. schulzii appears to be more closely related to $B$. apiculata apiculata than to $B$. oamaruensis. The illustrations of $B$. schulzii beside $B$. apiculata apiculata (see Martini and Müller, 1976, pl. 11, figs. 12 and 13) are quite convincing.

Bachmannocena triodon (Bukry) n. comb.

Mesocena triodon Bukry, 1973a, p. 860, pl. 2, fig. 11.

Bachmannocena venusta (Bukry) n. comb. Plate 2, Figs 2-4)

Mesocena venusta Bukry, 1977, p. 832, pl. 1, figs. 11-13.

\section{Genus CORBISEMA Hanna, 1928}

Corbisema amicula Bukry, n. sp.

(Plate 3, Figs. 2-6)

?Dictyocha triacantha fa. minor Schulz, 1928, p. 247, fig. 25b (not $25 \mathrm{a}$ or 26 ).

Description. Corbisema amicula has a small rounded basal ring with short spines. The struts are parallel-sided, except near the central junction, where they usually expand slightly into a small plate. The sides of the basal ring are convex, and there is no apparent basal pike at the strut junction.

Remarks. Corbisema amicula is distinguished from Corbisema triacantha convexa by the unflared junctions between the basal ring and struts, and by slightly more convex sides. Its small and rounded shape distinguished it among the late Eocene Corbisema species at Site 612. One drawn specimen of Schulz's (1928) composite taxon C. triacanthe fa. minor appears to be related to C. amicula. The lectotype specimen for C. triacantha fa. minor was designated previously (Bukry, 1978b) to be Schulz's (1928) fig. 25a.

Occurrence. Corbisema amicula is a minor species (1 to 10\%) at Site 612 in the upper Eocene of Cores 612-17, 612-18, and 612-20. Because upper Eocene silicoflagellates are little studied, the geography and potential usefulness of $C$. amicula have yet to be determined.

Size. Maximum internal diameter 15 to $22 \mu \mathrm{m}$.

Holotype. USNM 401464 (Plate 3, Fig. 2).

Isotypes. USNM 401465 to 401468.

Type locality. Western North Atlantic Ocean, DSDP Sample 612$18-1,100-101 \mathrm{~cm}$.

\section{Corbisema bimucronata elegans Bukry, $\mathbf{n}$. subsp.}

$$
\text { (Plate 3, Figs. 7-10) }
$$

Corbisema bimucronata Deflandre, Ling, 1972, p. 153, pl. 24, fig. 1. Corbisema bimucronata bimucronata Deflandre, Bukry, 1978b, p. 814 , pl. 1, fig. 2.

Description. Corbisema bimucronata elegans has a basal ring which is isosceles in general triangular form, but the apices are blunt and bear small spines at the ends of these blunt segments. The ratios of the long sides to the short sides (between spines) range from 1.14 to 1.46 (1.31 average). The struts are parallel-sided and there is a small pike on the basal ring at the junctions. The short side of the basal ring is more indented than the long sides.

Remarks. Corbisema bimucronata elegans is distinguished from C. bimucronata bimucronata by the isosceles symmetry of the basal ring, which has one short side and two long sides. It is distinguished from $C$. archangelskiana by less indented sides and small spines at the ends of the blunt apex segments.

The holotype figure of $C$. bimucronata bimucronata is the drawing of an apparently slightly tilted equilateral triangular ring, because the two shorter sides are nearly equal, whereas the third is distinctly longer. The central species concept of $C$. bimucronata bimucronata has been associated with essentially equilateral specimens (see Glezer, 1966, pl. 9, fig. 2; Bukry and Foster, 1974, fig. a; Bukry, 1978a, pl. 1, fig. 5; Bukry, 1975b, pl. 1, fig. 3; Perch-Nielsen, 1975, pl. 3, fig. 9). The significance of isosceles versus equilateral specimens has not been investigated yet. Investigations can be difficult because of the potential confusion between $C$. archangelskiana and presumably unspined $C$. bimucronata bimucronata (see Shaw and Ciesielski, 1983, pl. 1, figs. 4-6, and Loeblich et al., 1968, pl. 23, fig. 17-20).

Occurrence. Corbisema bimucronata elegans has been illustrated on the basis of specimens from the lower and upper Eocene of Atlantic localities on Barbados, and from DSDP Holes 390A, 612, and 613.

Size. Maximum internal diameter 28 to $34 \mu \mathrm{m}$.

Holotype. USNM 401469 (Plate 3, Fig. 8).

Isotypes. USNM 401470 to 401472.

Type locality. Western North Atlantic Ocean, DSDP Sample 612$17-3,100-101 \mathrm{~cm}$.

\section{Corbisema hastata incohata Bukry, n. subsp.}

(Plate 4, Figs. 6-10)

Description. Corbisema hastata incohata has a slightly asymmetric isosceles ring with a generally straight base and one side less convex than the other. A lopsided asymmetry results from the apex spine of the isosceles ring being above the basal portal abutting the least convex side, instead of symmetrically above the center of the basal side. The spine at the junction of the base and the least convex side is distinctly smaller than the other spines, and may even be missing. Some spines are not aligned in the plane of the ring. The ring-strut junctions are medially located, and basal pikes occur at those sites.

Remarks. Corbisema hastata incohata is most similar to $C$. hastata miranda, but is distinguished by the smallness of the spine at one end of the basal segment and by the distinct lopsided asymmetry of the ring, with some spines out of the plane of the ring.

Most specimens of $C$. hastata miranda (formerly $C$. hastata minor) have one basal spine slightly smaller than the other (see Bukry, 1975b; Martini and Müller, 1976), but the combination of lopsided ring symmetry and very small spine is used to distinguish $C$. hastata incohata as the product of a reduction in symmetry.

Occurrence. Corbisema hastata incohata occurs through the upper Eocene at DSDP Site 612, in Cores 612-17 to 612-20, in the lower Corbisema apiculata Zone and upper Dictyocha hexacantha Zone, both associated with the Isthmolithus recurvus Subzone (CP15b) of coccoliths. A reconnaissance of Sample 80010 from the Paracas Formation at Fundo Santa Rosa, Peru, shows the presence of $C$. hastata incohata at a coeval low-latitude site. Sample 80010 contains the interval of overlap between Bachmannocena apiculata apiculata and Dictyocha hexacantha, which matches the $C$. hastata incohata occurrence at Site 612 . This correlative sample was originally provided to Dr. John Barron (U.S. Geological Survey) for diatom dating by Dr. José Macharé (Université de Paris Sud), and both diatoms and silicoflagellates indicate a late Eocene age for the sample.

A total range of $C$. hastata incohata is not known, because it may have been tabulated previously with more symmetric $C$. hastata miran$d a$ (formerly $C$. hastata minor).

Size. Maximum internal diameter 23 to $26 \mu \mathrm{m}$.

Holotype. USNM 401473 (Plate 4, Fig. 6).

Isotypes. USNM 401474 to 401477.

Type locality. Western North Atlantic Ocean, DSDP Sample 612$17-3,100-101 \mathrm{~cm}$.

\section{Corbisema jerseyensis Bukry, n. sp.} (Plate 5, Figs. 1-3)

Description. Corbisema jerseyensis has a small, narrow, isosceles ring with a rather smooth non-sulcate outline. The base is nearly flat. Spines are of moderate length and there are no apparent basal pikes. The apical bars are parallel-sided.

Remarks. Corbisema jerseyensis is distinguished from similar $C$. hastata globulata by the narrower base and smoother sides of the isosceles ring. It is distinguished from $C$. hastata cunicula by much shorter spines and taller, more equant basal portals.

Occurrence. Corbisema jerseyensis occurs principally in the upper Eocene lower Corbisema apiculata Zone and upper Dictyocha hex- 
acantha Zone of Site 612. It is most abundant $(9 \%)$ in the C. apiculata Zone, and ranges through Cores 612-22 to 612-17.

Size. Maximum internal diameter 18 to $21 \mu \mathrm{m}$.

Holotype. USNM 401478 (Plate 5, Fig. 2).

Isotypes. USNM 401479 and 401480.

Type locality. Western North Atlantic Ocean, DSDP Sample 61220-5, 100-101 cm.

\section{Genus DICTYOCHA Ehrenberg, 1837}

Dictyocha acuta Bukry, n. sp.

(Plate 5. Figs. 8, 9; Plate 6, Figs. 1-3)

?Dictyocha aff. fibula var. rhombus (Hack.) Lemm., Glezer, 1966, p. 270 , pl. 9 , fig. 3 .

Dictyocha aspera (Lemmermann, 1901) s. ampl., Dumoulin, 1979, p. 92 , pl. 2, figs. 3, 4, 6. (Unpublished.)

?Dictyocha fibula Ehrenberg, Shaw and Ciesielski, 1983 (in part), p. 711 , pl. 4, figs. 1, 3, 4 (not fig. 2). (?Asperoid cold-water phenotypes.)

Description. Dictyocha acuta has a straight-sided regular rhomboid ring with moderate to long spines aligned with both the major and minor axes. The apical bar is short and canted from the lines of axial symmetry, typically more closely aligned with the major axis. The strut junctions with the ring are strongly offset, dividing the sides of the ring at a third to a fifth of the distance between spines. Small basal pikes are present, well offset from the strut-ring junctions. The ratio of major axis to minor axis, measured along the ring internal diameters, ranges from 1.1 to 1.3 . Spine length are typically equal to or slightly less than the aligned ring inner diameter.

Remarks. Dictyocha acuta is distinguished from Miocene D. fibula fibula (as illustrated by Ehrenberg, 1854, and discussed in Bukry, 1978a and 1983) by canted bar, asymmetric strut junctions, angular ring, and longer minor-axis spines. It is distinguished from Eocene $D$. byronalis by straight-sided ring and from younger $D$. stapedia aspino$s a, D$. fibula augusta, and $D$. concavata by canted bar.

Occurrence. Dictyocha acuta occurs in upper Eocene Sample 612$20-1,100-101 \mathrm{~cm}$, in the stratigraphic interval where $D$. hexacantha and Bachmannocena apiculata apiculata overlap. Dumoulin (1979, 1984) reported the occurrence of this new species in the middle to upper Eocene of Kreyenhagen Formation in California, in the same stratigraphic interval where $D$. hexacantha and $B$. apiculata apiculata overlap in the upper Dictyocha hexacantha Zone. The questionably compared specimens of the synonymy occur in samples that were assigned to the upper Eocene (USSR) and middle Eocene (Falkland Plateau).

Size. Basal ring major-axis length 28 to $33 \mu \mathrm{m}$.

Holotype. USNM 401481 (Plate 6, Fig. 2).

Isotypes. USNM 401482 to 401484 .

Type locality. Western North Atlantic Ocean, DSDP Sample 61220-1, 100-101 cm.

\section{Diatoms}

\section{Genus COSCINODISCUS Ehrenberg, 1838 \\ Coscinodiscus eomonoculus Bukry, n. sp. (Plate 7, Figs. 6-9)}

Coscinodiscus? sp. Bukry, 1978c, p. 804, pl. 7, figs. 11, 12.

Coscinodiscus sp. Bukry, 1978 b, p. 842 , pl. 9 , figs. 4 , 5 .

Description. Coscinodiscus eomonoculus is small to moderate in size and circular with a distinctive large central areola. The valve surface elevates gradually from the margin to the central areola. The central areola is polygonal and variable, ranging from 7 - to 10 -sided. The other areolae are hexagonal (rarely pentagonal) and arrayed in primary radial rows of 3 to 5 areolae, which decline in size toward the margin. The large central areola is 5 to $10 \mu \mathrm{m}$ in diameter, whereas the largest adjoining radial areola is 3 to $6 \mu \mathrm{m}$, and the smallest areola, at the margin, is about 1 to $2.5 \mu \mathrm{m}$. Proportionally, the central areola is 10 to $20 \%$ as wide as the whole valve, and it is only slightly less than twice as large as the adjoining areolae. The smallest radial areolae are about half the size of the largest ones in the apical cycle around the central areola.

Remarks. Coscinodiscus eomonoculus is distinguished from other Eocene diatoms by the distinctive large central areola and the declining size of the other areolae in rows to the margin. It is so distinctive that in some samples from Site 613 it could be identified from a fragment when only the central areola and one adjoining cycle of areolae were preserved.

Occurrence. Coscinodiscus eomonoculus is a minor species which is known to range from the lower Eocene Zone CP11 of coccoliths and lower Dictyocha spinosa Zone of silicoflagellates at DSDP Hole 390A to the middle Eocene Subzone CP13a of coccoliths and the upper Dictyocha spinosa Subzone of silicoflagellates at DSDP Hole 613. Therefore, it has a range off the east coast of the United States that spans the lower Eocene to middle Eocene boundary. Besides Leg 95 sites, it occurs at DSDP Holes 385 (Cores 385-4 to 385-6) and 390A (Cores $390 \mathrm{~A}-5$ to $390 \mathrm{~A}-6$ ). It is missing in the middle and upper Eocene samples from DSDP Hole 612. At Hole 613 it ranges from Sample 613-38-

1, 100-101 cm to Sample 613-31-3, 100-101 cm.

Size. Maximum diameter 29 to $75 \mu \mathrm{m}$.

Holotype. USNM 401485 (Plate 7, Figs. 6, 7).

Isotopes. USNM 401486 and 401487.

Type locality. Western North Atlantic Ocean, DSDP Sample 613$36-5,100-101 \mathrm{~cm}$.

\section{LIST OF OTHER SILICOFLAGELLATE TAXA CITED}

Bachmannocena circulus (Ehrenberg, 1840) Locker, 1974

B. diodon diodon (Ehrenberg, 1844) Locker, 1974

B. triangula (Ehrenberg, 1839) Locker, 1974

Corbisema angularis Bukry in Barron, Bukry, and Poore, 1984

C. apiculata (Lemmermann, 1901) Hanna, 1931

C. archangelskiana (Schulz, 1928) Frenguelli, 1940

C. bimucronata bimucronata Deflandre, 1950

C. bimucronata rotatoria Bukry, 1977

C. disymmetrica communis Bukry, 1976

C. ellipsis Dumoulin, 1984

C. exilis Bukry in Barron, Bukry, and Poore, 1984

C. hastata cunicula Bukry, 1976

C. hastata globulata Bukry, 1976

C. hastata hastata (Lemmermann, 1901) Frenguelli, 1940

C. hastata miranda Bukry in Barron, Bukry, and Poore, 1984

C. inermis ballantina Bukry in Barron, Bukry, and Poore, 1984

C. inermis inermis (Lemmermann, 1901) Dumitricà, 1973

C. inermis minor (Glezer, 1966) Bukry, 1976

C. katharinae Bukry, 1976

C. lamellifera (Glezer, 1962) Bukry, 1977

C. recta (Schulz, 1928) Ling, 1972

C. regina Bukry in Barron, Bukry, and Poore, 1984

C. toxeuma Bukry, 1978

C. triacantha convexa Bukry, 1978

C. triacantha mediana Bukry, 1978

C. triacantha triacantha (Ehrenberg, 1844) Hanna, 1928

Dictyocha aspera (Lemmermann, 1901) Bukry and Foster, 1973

D. brevispina (Lemmermann, 1901) Bukry, 1976

D. byronalis Bukry in Barron, Bukry, and Poore, 1984

D. concavata Dumitrică, 1978

D. deflandrei completa Glezer, 1966

D. deflandrei deflandrei Frenguelli ex Glezer, 1966

D. deflandrei lobata Bukry, 1978

D. dickii Dumoulin, 1984

D. fibula augusta Bukry, 1976

D. fibula fibula Ehrenberg, 1839

D. hexacantha Schulz, 1928

D. perlaevis Frenguelli, 1951

D. spinosa (Deflandre, 1950) Glezer, 1966

D. stapedia aspinosa Bukry, 1976

Distephanus crux (Ehrenberg, 1840) Haeckel, 1887

D. quinquangellus Bukry and Foster, 1973

D. speculum hemisphaericus (Ehrenberg, 1844) Bukry, 1975

D. speculum speculum (Ehrenberg, 1839) Haeckel, 1887

D. speculum triommata (Ehrenberg, 1845) Bukry, 1976

Naviculopsis biapiculata (Lemmermann, 1901) Frenguelli, 1940

N. constricta (Schulz, 1928) Frenguelli, 1940

N. eobiapiculata Bukry, 1978

N. foliacea Deflandre, 1950

N. nordica nordica Bukry, 1976

N. punctilia punctilia Perch-Nielsen, 1976

N. trispinosa (Schulz, 1928) Glezer, 1962

Incertae sedis 
Macrora barbadensis (Deflandre, 1938) Bukry, 1977

Macrora najae Bukry, 1977

Macrora stella (Azpeitia, 1911) Hanna, 1932

\section{SUMMARY}

The main results of this study of Eocene phytoplankton from Leg 95 are summarized here:

1. The upper middle Eocene silicoflagellates of the Dictyocha hexacantha Zone at Site 612 are remarkably similar to coeval assemblages from the Kellogg Shale of California and from Site 356 in the South Atlantic.

2. Mid-latitude upper middle Eocene assemblages can be biostratigraphically correlated using siliceous phytoplankton Bachmannocena oamaruensis, B. venusta, Dictyocha hexacantha, D. spinosa, Macrora barbadensis, and $M$. najae, and calcareous phytoplankton Chiasmolithus grandis and Discoaster bifax.

3. The lower middle Eocene section at Site 613 has sparse silicoflagellates and a new diatom, Coscinodiscus eomonoculus, which have rarely been recovered before by deep-sea drilling.

4. Biostratigraphic and skeletal morphology trends observed in samples from Sites 612 and 613 suggest several potential evolutionary lineages: from Bachmannocena connudata to $B$. venusta; from $B$. venusta to $B$. oamaruensis; from $B$. oamaruensis to $B$. apiculata apiculata; from $B$. apiculata apiculata to $B$. apiculata monolineata; from Corbisema hastata miranda to $C$. hastata incohata; and from Macrora barbadensis to M. stella.

5. Generic paleotemperature keys are less useful in the Paleogene than in the Neogene, judging by a test of the Corbisema/Naviculopsis ratio, $\mathrm{C} / \mathrm{N}$, between Leg 95 sites and other middle- and high-latitude locations.

6. Species distributions within genus Naviculopsis may prove to be the best silicoflagellate guide to relative paleotemperature analysis of the Paleocene.

7. Major differences in the middle and upper Eocene species arrays between mid-latitude assemblages, Falkland high-latitude assemblages, and Arctic/Norwegian high-latitude assemblages, suggest that at least three distinct ecologic provinces of silicoflagellates can be identified. The mid-latitude province, typified by Sites 612 and 613 , is the largest, spanning nearly $70^{\circ}$ of latitude, from Site 612 to Site 356 in the Atlantic.

\section{ACKNOWLEDGMENTS}

I thank John Barron and Paula Quinterno, U.S Geological Survey, Menlo Park, for their constructive peer reviews of the manuscript. I also appreciate the excellent editorial reviews done by Amanda Palmer, ODP, and Wylie Poag, U.S. Geological Survey, Woods Hole. John Barron provided reference slides of the Paracas Formation of Peru and valuable discussions on phytoplankton paleontology. This study of Leg 95 was also expedited by the support of Paul Schiffelbein (DSDP), Amanda Palmer (ODP), Jan Blakeslee (DSDP), and Christine Mato (ODP), in addition to an excellent sample array taken on board the Glomar Challenger during Leg 95. Finally, I thank my secretary, Dorothy Blackstock, for conscientious and unflagging support in the preparation of the final manuscript.

\section{REFERENCES}

Bachmann, A., 1962. Eine neue Mesocena-Art (Silicoflagellidae) aus dem kalifornischen Eozän. Osterreichische Geol. Bundesanst. Verh., Jb. 1962:378-383.
1970. Silicoflagellaten aus dem oberösterreichischen Egerien (Oberoligozän). Osterreichische Geol. Bundesanst. Verh., 2: 275-305.

Barron, J. A., Bukry, D., and Poore, R. Z., 1984. Correlation of the middle Eocene Kellogg Shale of northern California. Micropaleontology, 30:138-170.

Bukry, D., 1973a. Coccoliths and silicoflagellates from Deep Sea Drilling Project Leg 19, North Pacific Ocean and Bering Sea. In Creager, J. S., Scholl, D. W., et al., Init. Repts. DSDP, 19: Washington (U.S. Govt. Printing Office), 857-867.

1973b. Low-latitude coccolith biostratigraphic zonation. In Edgar, N. T., Saunders, J. B., et al., Init. Repts. DSDP, 15: Washington (U.S. Govt. Printing Office), 685-703.

1975a. Coccolith and silicoflagellate stratigraphy, northwestern Pacific Ocean, Deep Sea Drilling Project Leg 32. In Larson, R. L., Moberly, R., et al., Init. Repts. DSDP, 32; Washington (U.S. Govt. Printing Office), 677-701.

1975b. Silicoflagellate and coccolith stratigraphy, Deep Sea Drilling Project Leg 29. In Kennett, J. P., Houtz, R. E., et al., Init. Repts. DSDP, 29: Washington (U.S. Govt. Printing Office), 845-872.

1976a. Cenozoic silicoflagellate and coccolith stratigraphy, South Atlantic Ocean, Deep Sea Drilling Project Leg 36. In Hollister, C. D., Craddock, C., et al., Init. Repts. DSDP, 35: Washington (U.S. Govt. Printing Office), 885-917.

1976b. Silicoflagellate and coccolith stratigraphy, Norwegian-Greenland Sea, Deep Sea Drilling Project Leg 38. In Talwani, M., Udintsev, G., et al., Init. Repts. DSDP, 38: Washington (U.S. Govt. Printing Office), 843-855.

1977. Coccolith and silicoflagellate stratigraphy, South Atlantic Ocean, Deep Sea Drilling Project Leg 39. In Supko, P. R., Perch-Nielsen, K., et al., Init. Repts. DSDP, 39: Washington (U.S. Govt. Printing Office), 825-839.

1978a. Cenozoic coccolith and silicoflagellate stratigraphy, offshore northwest Africa, Deep Sea Drilling Project Leg 41. In Lancelot, Y., Seibold, E., et al., Init. Repts. DSDP, 41: Washington (U.S. Govt. Printing Office), 689-707.

1978b. Cenozoic coccolith, silicoflagellate, and diatom stratigraphy, Deep Sea Drilling Project Leg 44. In Benson, W. E., Sheridan, R. E., et al., Init. Repts. DSDP, 44: Washington (U.S. Govt. Printing Office), 807-863.

1978c. Cenozoic silicoflagellate and coccolith stratigraphy, northwestern Atlantic Ocean, Deep Sea Drilling Project Leg 43. In Benson, W. E., Sheridan, R. E., et al., Init. Repts. DSDP, 44: Washington (U.S. Govt. Printing Office), 775-805.

1981a. Silicoflagellate stratigraphy of offshore California and Baja California, Deep Sea Drilling Project Leg 63. In Yeats, R. S., Haq, B. U., et al., Init. Repts. DSDP, 63: Washington (U.S. Govt. Printing Office), 539-557.

$1981 \mathrm{~b}$. Synthesis of silicoflagellate stratigraphy for Maestrichtian to Quaternary marine sediment. Soc. Econ. Paleontol. Mineral. Spec. Publ., 32:433-444.

1983. Upper Cenozoic silicoflagellates from offshore Ecuador, Deep Sea Drilling Project Site 504. In Cann, J. R., Langseth, M. G., Honnorez, J., Von Herzen, R. P., White, S. M., et al., Init. Repts. DSDP, 69: Washington (U.S. Govt. Printing Office), 321342 .

1984 [1985]. Cenozoic silicoflagellates from Rockall Plateau, Deep Sea Drilling Project Leg 81. In Roberts, D. G., Schnitker, D., et al., Init. Repts. DSDP, 81: Washington (U.S. Govt. Printing Office), 547-563.

1985. Tropical Pacific silicoflagellate zonation and paleotemperature trends of the late Cenozoic. In Mayer, L., Theyer, F., et al., Init. Repts. DSDP, 85: Washington (U.S. Govt. Printing Office), 477-497.

1986. Miocene silicoflagellates from Chatham Rise, Deep Sea Drilling Project Site 594. In Kennett, J. P., von der Borch, C. C., et al., Init. Repts. DSDP, 90, Pt. 2: Washington (U.S. Govt. Printing Office), 925-937.

Bukry, D., and Foster, J. H., 1974. Silicoflagellate zonation of Upper Cretaceous to lower Miocene deep-sea sediment. U.S. Geol. Sur. J. Res., 2:303-310.

Ciesielski, P. F., 1975. Biostratigraphy and paleoecology of Neogene and Oligocene silicoflagellates from cores recovered during Ant- 
arctic Leg 28, Deep Sea Drilling Project. In Hayes, D. E., Frakes, L. A., et al., Init. Repts. DSDP, 28: Washington (U.S. Govt. Printing Office), 625-691.

Deflandre, G., 1932. Sur la systématique des Silicoflagellés. Bull. Soc. Bot. Fr., 79:494-506.

Dumitrică, P., 1973. Paleocene, late Oligocene and post-Oligocene silicoflagellates in southwestern Pacific sediments cored on DSDP Leg 21. In Burns, R. E., Andrews, J. E., et al., Init. Repts. DSDP, 21: Washington (U.S. Govt. Printing Office), 837-883.

Dumoulin, J. A., 1979. Eocene-Oligocene silicoflagellates of the Kreyenhagen Formation, Fresno County, California [M.S. thesis]. University of Wisconsin, Madison.

1984. Silicoflagellate biostratigraphy and paleoecology of the upper Kreyenhagen Formation (Eocene-Oligocene), California. In Blueford, J. R. (Ed.), Kreyenhagen Formation and Related Rocks. Pacific Section Soc. Econ. Paleontol. Mineral, Book 37:29-49.

Ehrenberg, C. G., 1840. Blätter von ihm selbst ausgeführter Zeichnungen von ebenso vielen Arten. K. Preuss. Akad. Wiss. Berlin Ber., Jahrg. 1840:197-219 (Nov.).

1843. Verbreitung und Einfluss des mikroskopischen Lebens in Süd- und Nord-Amerika. Akad. Wiss. Berlin Abh., 1841, pp. 291-446.

1844. Mittheilung über zwei neue Lager von Gebirgsmassen aus Infusorien als Meeres-Absatz in Nord-Amerika und eine Vergleichung derselben mit den organischen Kreide-Gebilden in Europa und Afrika. K. Preuss. Akad. Wiss, Berlin Ber., Jahrg. 1844:5797.

1854. Mikrogeologie: Leipzig (Leopold Voss), pp. 1-374.

Frenguelli, J., 1940. Consideraciones sobre los silicoflagelados fósiles. Mus. La Plata Rev. Paleontol., 2(7):37-112.

Gemeinhardt, K., 1934. Die Silicoflagellaten des südatlantischen Ozeans. Wiss. Ergebnisse der deutschen Atlantischen Expedition auf den Forschungs- und Vermessungsschiff "Meteor" 1925-1927, 12(1):274-312.

Glezer, Z. I., 1964. Novye kremnevye zhgutikovye vodorosli Paleogena SSSR [New silicoflagellates from the Paleogene of the USSR]. Akad. Nauk SSSR, Novosti sistematiki nizshikh rasteniy, otdel. ottisk., pp. 46-58.

, 1966. Silicoflagellatophyceae. In Gollerbakh, M. M. (Ed.), Cryptogamic plants of the U.S.S.R. Akad. Nauk SSSR, V. A. Komarova Bot. Inst., 7:1-363. (Translated from Russian by Israel Program for Scientific Translations Ltd., Jerusualem, 1970.)

Haeckel, E. H. P. A., 1887. Cannorrhaphida. Challenger Rept., 18: 1546-1569.

Kennett, J. P., 1977. Cenozoic evolution of Antarctic glaciation, the circum-Antarctic Ocean, and their impact on global paleoceanography. J. Geophys. Res., 82:3843-3860.
Lanjouw, J., Mamay, S. H., McVaugh, R., et al. (Eds.), 1966. International Code of Botanical Nomenclature Adopted by the Tenth International Botanical Congress, Edinburgh, August 1964: Utrecht (International Bureau for Plant Taxonomy and Nomenclature).

Lemmermann, E., 1901. Silicoflagellatae. Deutsche. Bot. Gesell. Ber., $19: 247-271$.

Ling, H. Y., 1972. Upper Cretaceous and Cenozoic silicoflagellates and ebridians. Bulls. Am. Paleontol., 62:135-229.

Ling, H. Y., and Takahashi, K., 1985. The silicoflagellate genus Octactis Schiller 1925: A synonym of the genus Distephanus. Micropaleontology, 31:76-81.

Locker, S., 1974. Revision der Silicoflagellaten aus der Mikrogeologischen Sammlung von C. G. Ehrenberg. Eclogae. Geol. Helv., 67: 631-646.

Loeblich, A. R., III, Loeblich, L. A., Tappan, H., and Loeblich, A. R., Jr., 1968. Annotated index of fossil and recent silicoflagellates and ebridians with descriptions and illustrations of validly proposed taxa. Mem. Geol. Soc. Am., 106:1-319.

Martini, E., 1981. Silicoflagellaten im Paläogen von Norddeutschland. Senckenbergiana Lethaea, 62:277-283.

Martini, E., and Müller, C., 1976. Eocene to Pleistocene silicoflagellates from the Norwegian-Greenland Sea (DSDP Leg 38). In Talwani, M., Udintsev, G., et al., Init. Repts. DSDP, 38: Washington (U.S. Govt. Printing Office), 857-895.

Okada, H., and Bukry, D., 1980. Supplementary modification and introduction of code numbers to the low-latitude coccolith biostratigraphic zonation (Bukry, 1973; 1975). Mar. Micropaleontol., 5: 321-325.

Perch-Nielsen, K., 1975. Late Cretaceous to Pleistocene silicoflagellates from the southern southwest Pacific, DSDP Leg 29. In Kennett, J. P., Houtz, R. E., et al., Init. Repts. DSDP, 29: Washington (U.S. Govt. Printing Office), 677-721.

1976. New silicoflagellates and a silicoflagellate zonation in north European Palaeocene and Eocene diatomites. Geol. Soc. Denmark Bull., 25:27-40.

Schulz, P., 1928. Beiträge zur Kenntnis fossiler und rezenter Silicoflagellaten. Bot. Archiv., 21:225-292.

Shaw, C. A., and Ciesielski, P. F., 1983. Silicoflagellate biostratigraphy of middle Eocene to Holocene subantarctic sediments recovered by Deep Sea Drilling Project Leg 71. In Ludwig, W. J., Krasheninnikov, V. A., et al., Init. Repts. DSDP, 71: Washington (U.S. Govt. Printing Office), 687-737.

Tsumura, K., 1963. A systematic study of Silicoflagellatae. Yokohama Municipal Univ. J., Ser. C-45, No. 146:1-84.

Van Valkenburg, S. D., 1980. Silicoflagellates. In Cox, E. R. (Ed.), Phytoflagellates: New York (Elsevier North Holland, Inc.), pp. 335-350. 


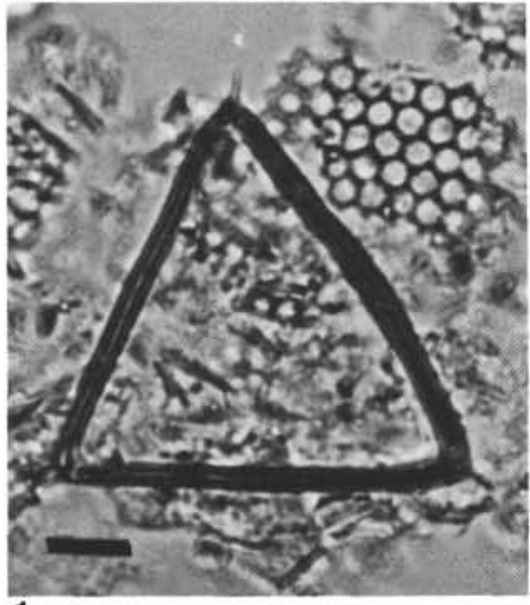

1
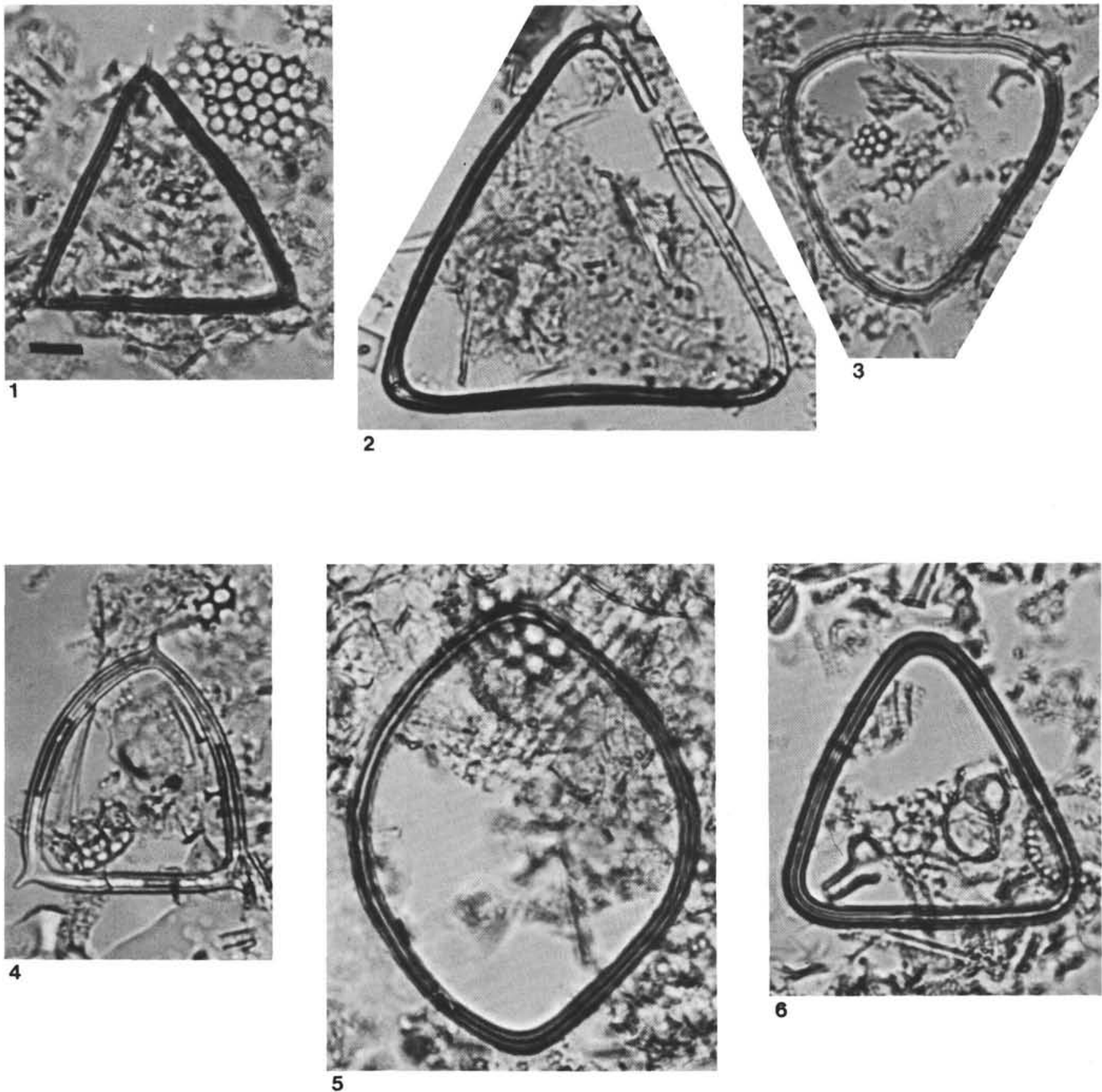

6

Plate 1. Eocene silicoflagellates from DSDP Leg 95. (Scale bar $=10 \mu \mathrm{m}$.) 1. Bachmannocena apiculata apiculata (Schulz), Sample 612-19-1, 100-101 cm. 2. Bachmannocena sp. cf. B. apiculata apiculata (Schulz), unspined specimen, Sample 612-21-1, 100-101 cm. 3. Bachmannocena apiculata inflata (Bukry), Sample 613-31-3, 100-101 cm. 4. Bachmannocena apiculata monolineata Bukry, n. subsp., holotype, USNM 401463, Sample 612-17-3, 100-101 cm. 5. Bachmannocena connudata (Bukry), Sample 613-37-3, 100-101 cm. 6. Bachmannocena oamaruensis (Schulz), Sample 612-22-5, 100-101 cm. 


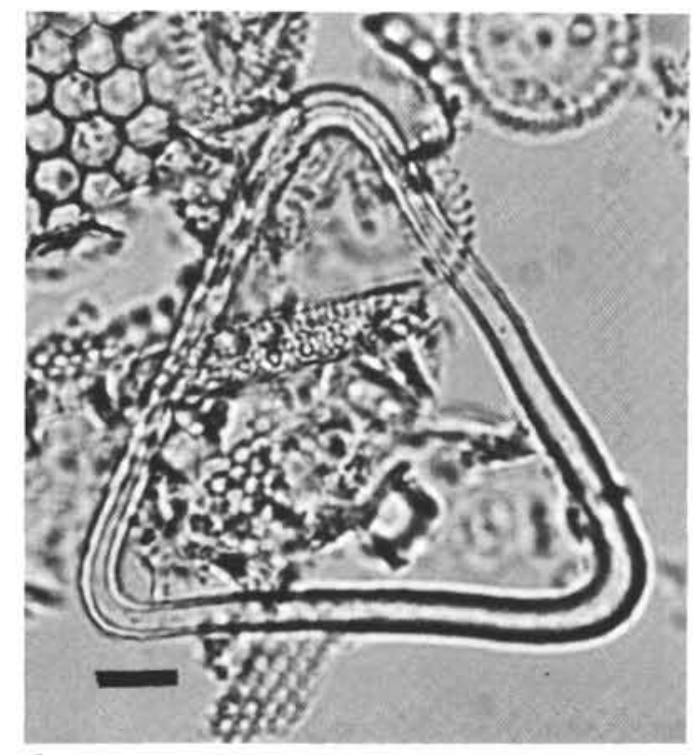

1

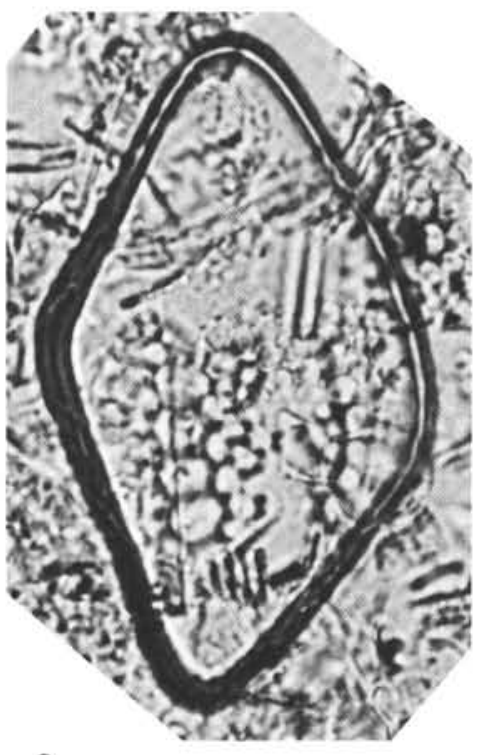

2

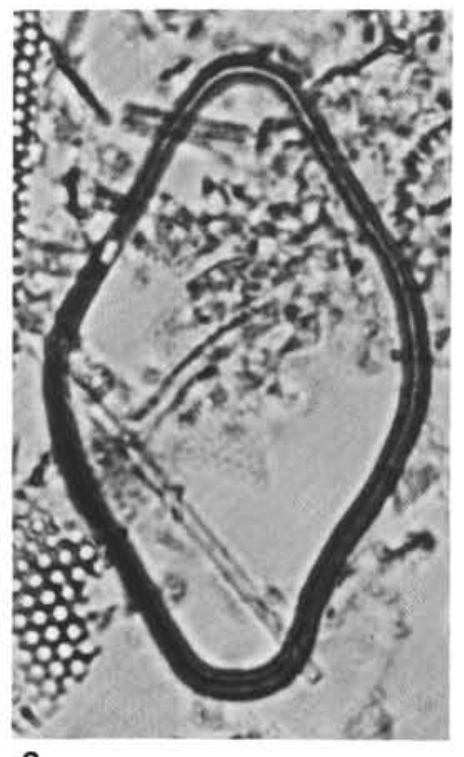

3

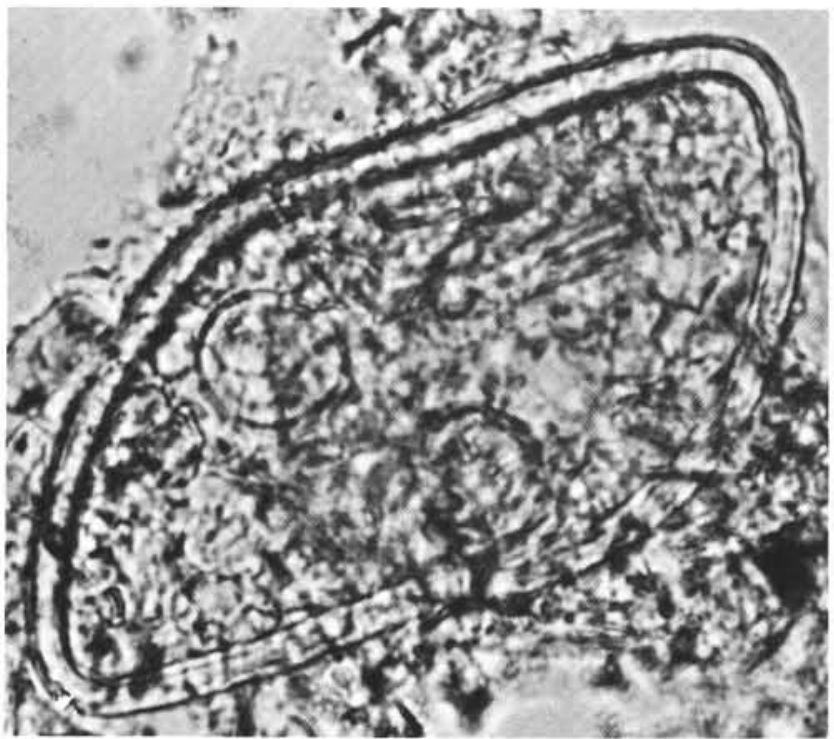

4

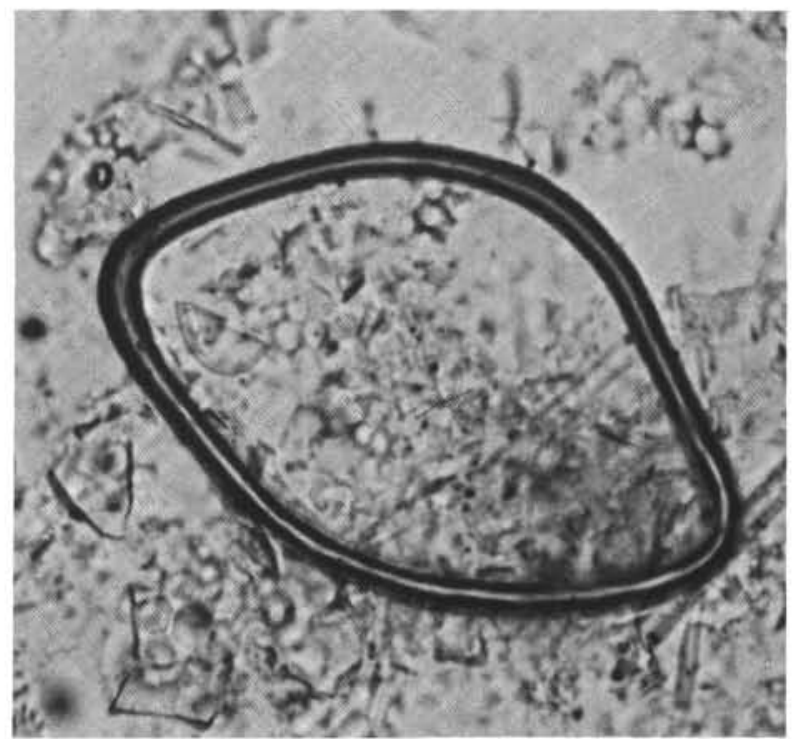

5

Plate 2. Eocene silicoflagellates from DSDP Leg 95. (Scale bar $=10 \mu \mathrm{m}$.) 1. Bachmannocena oamaruensis (Schulz), Sample 612-23-5, 100-101 $\mathrm{cm}$. 2-4. Bachmannocena venusta (Bukry), (2) typical form, Sample 612-22-1, 100-101 cm, (3) Sample 612-25-1, 100-101 cm, (4) Sample 613$37-13,100-101 \mathrm{~cm}$. 5. Bachmannocena sp. cf. B. venusta (Bukry) (lower side suggests affinity with B. connudata [Bukry]), Sample 612-26-5, $100-101 \mathrm{~cm}$. 


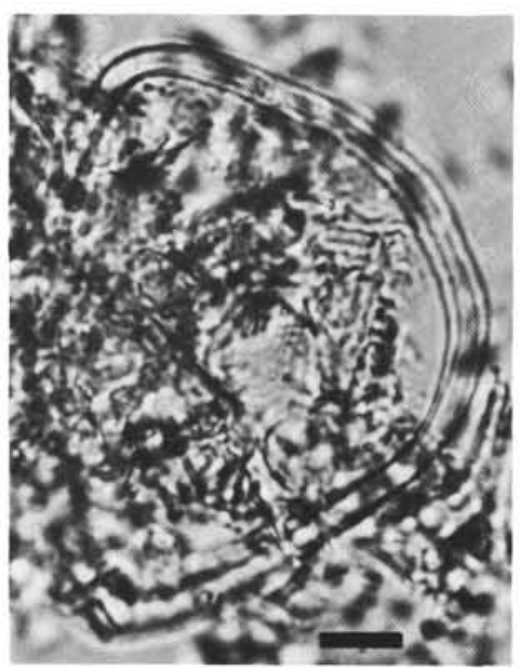

1

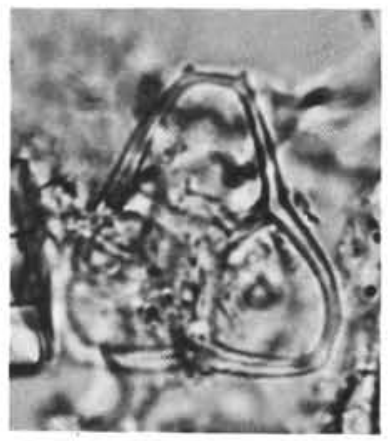

7

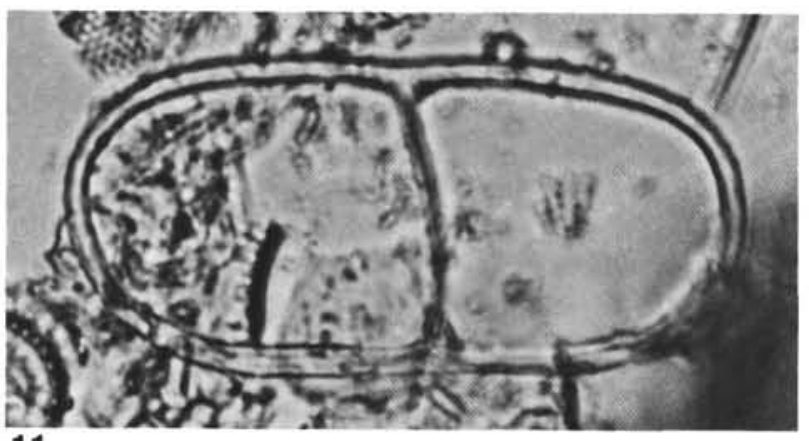

11

2

8
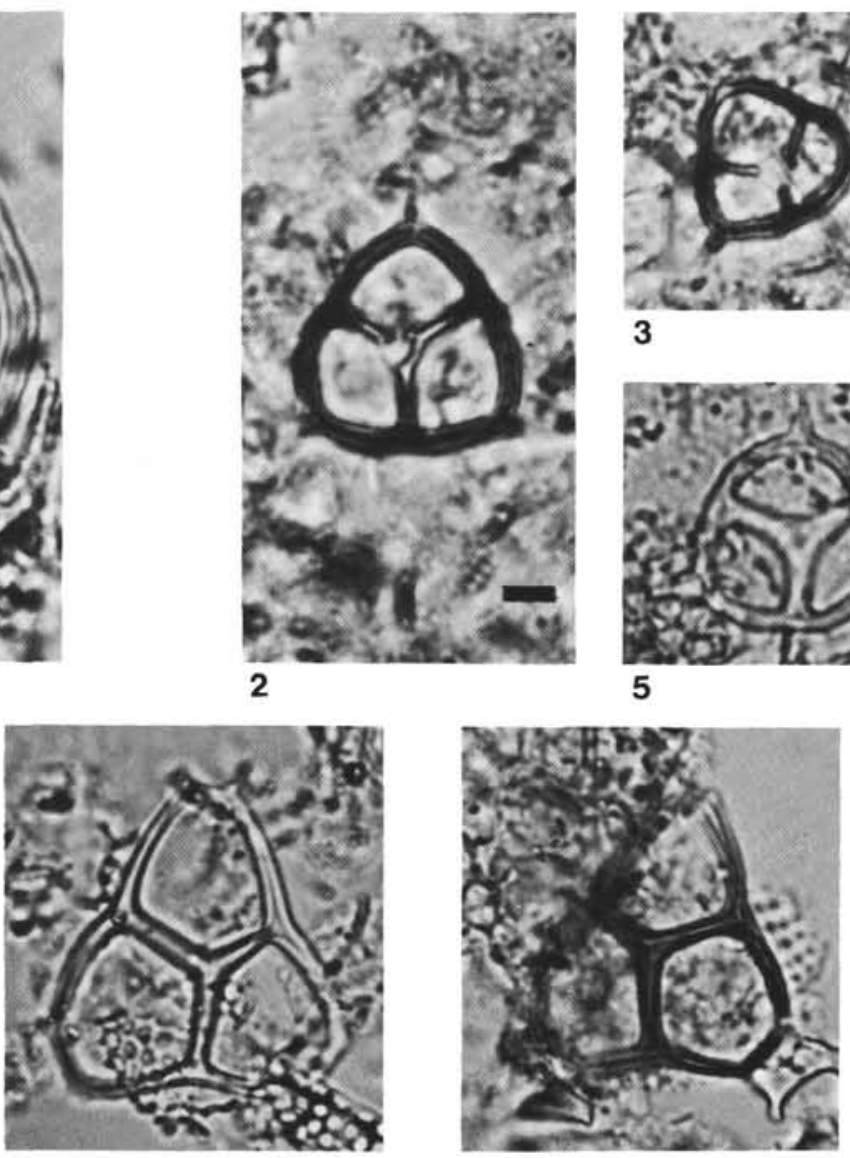

9

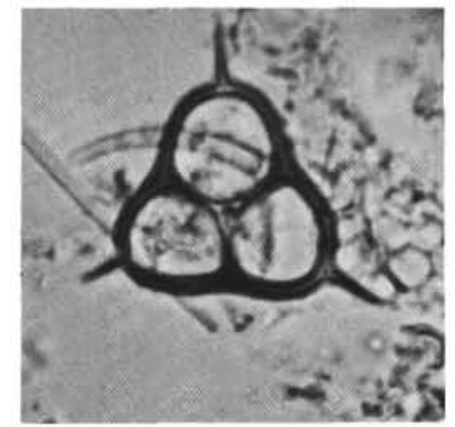

12

Plate 3. Eocene silicoflagellates from DSDP Leg 95. (Scale bar $=10 \mu \mathrm{m}$ for all figures except Fig. 2; that bar $=5 \mu \mathrm{m}$.) 1. Bachmannocena sp. cf. B. venusta (Bukry) (modified form suggests affinity with B. oamaruensis [Schulz]), Sample 612-24-5, 100-101 cm. 2-6. Corbisema amicula Bukry, n. sp., (2) holotype, USNM 401464, Sample 612-18-1, 100-101 cm, (3) USNM 401465, Sample 612-18-1, 100-101 cm, (4) USNM 401466, Sample 612-18-1, 100-101 cm, (5) USNM 401467, Sample 612-20-5, 100-101 cm, (6) USNM 401468, Sample 612-18-1, 100-101 cm. 7-10. Corbisema bimucronata elegans Bukry, n. subsp., (7) USNM 401470, Sample 612-17-3, 100-101 cm, (8) holotype, USNM 401469, Sample 612-17-3, 100-101 cm, (9) USNM 401471, Sample 612-17-3, 100-101 cm, (10) USNM 401472, Sample 612-18-1, 100-101 cm. 11. Corbisema disymmetrica communis Bukry, Sample 613-35-3, 100-101 cm. 12. Corbisema hastata globulata Bukry, Sample 612-33-5, 100-101 cm. 

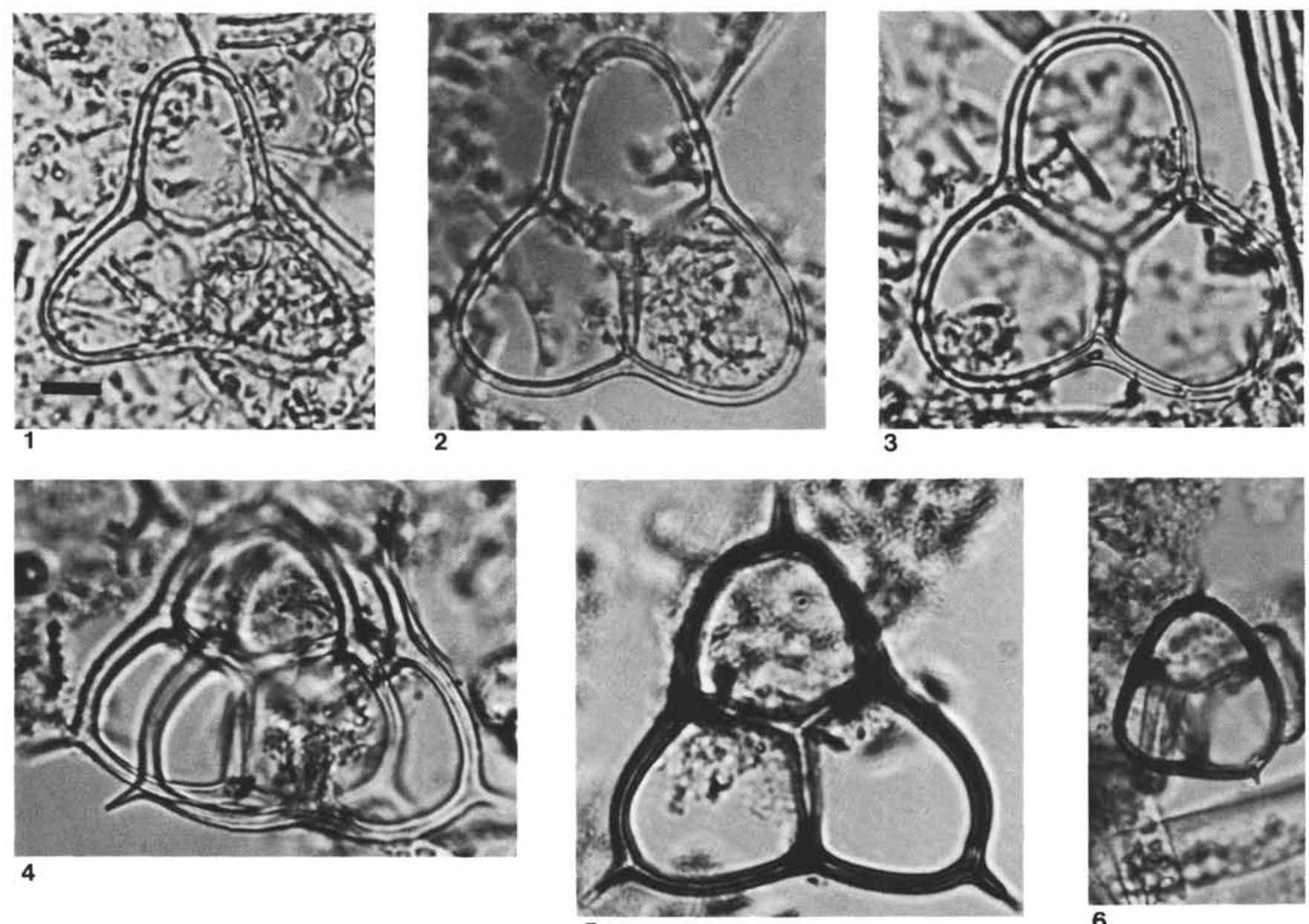

5

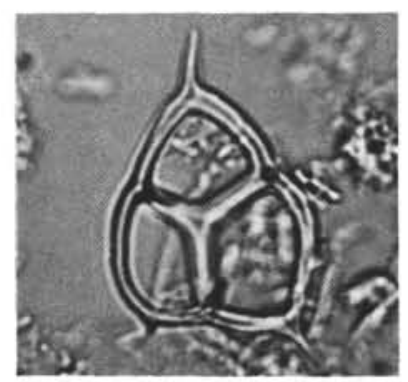

7

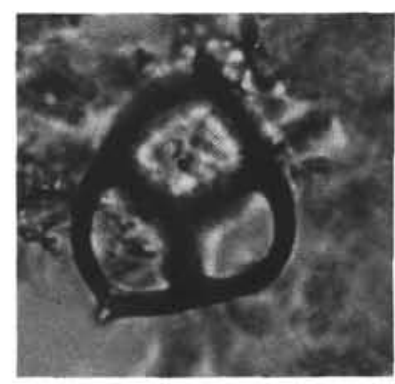

8

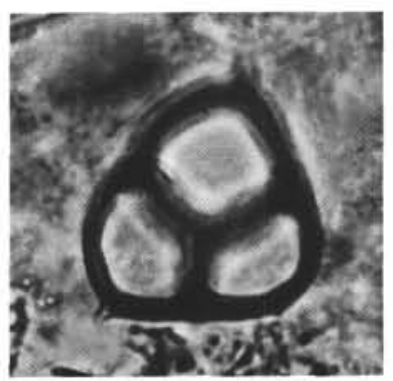

9

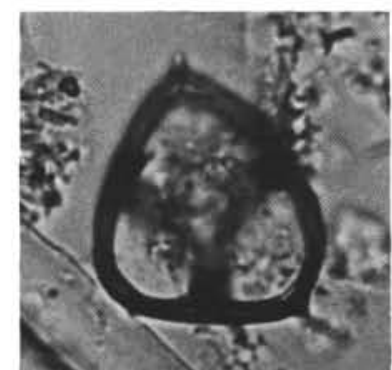

10

Plate 4. Eocene silicoflagellates from DSDP Leg 95. (Scale bar $=10 \mu \mathrm{m}$.) 1. Corbisema archangelskiana (Schulz), Sample 613-27-5, 100-101 $\mathrm{cm}$. 2-3. Corbisema inermis ballantina Bukry, (2) isosceles shape, Sample 613-29-5, 100-101 cm, (3) typical shape, Sample 612-22-1, 100-101 $\mathrm{cm}$. 4. Corbisema apiculata apiculata (Lemmermann), paired skeletons, Sample 612-17-3, 100-101 cm. 5. Corbisema ellipsis Dumoulin, Sample 612-21-3, 100-101 cm. 6-10.Corbisema hastata incohata Bukry, n. subsp., (6) holotype, USNM 401473, Sample 612-17-3, 100-101 cm, (7) USNM 401474, Sample JM 80010 Paracas Formation Peru, (8) USNM 401475, Sample 612-20-1, 100-101 cm, (9) USNM 401476, Sample $612-18-1,100-101 \mathrm{~cm},(10)$ USNM 401477, Sample 612-17-3, 100-101 cm. 


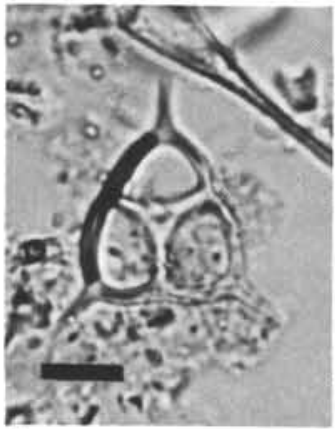

1

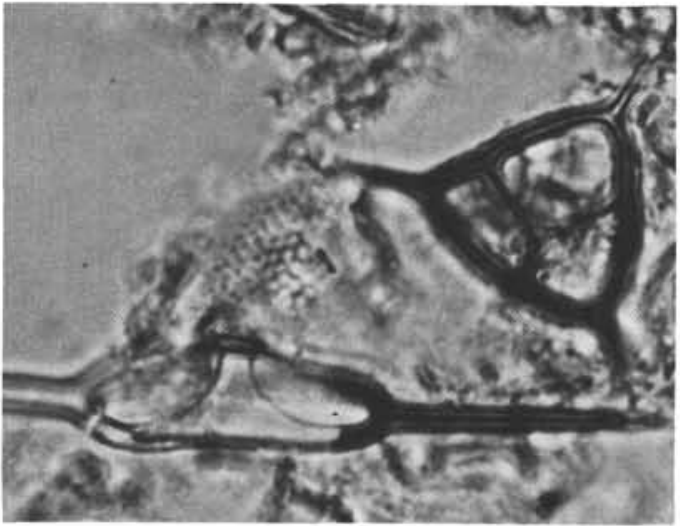

5

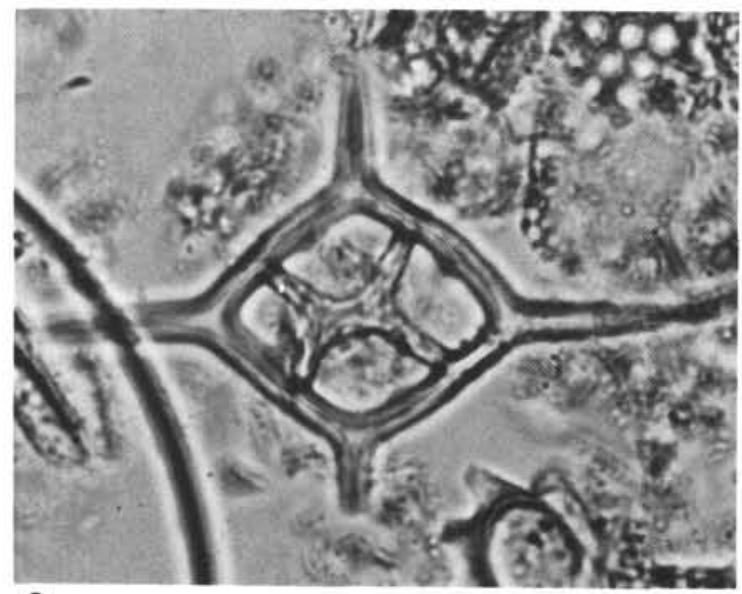

8

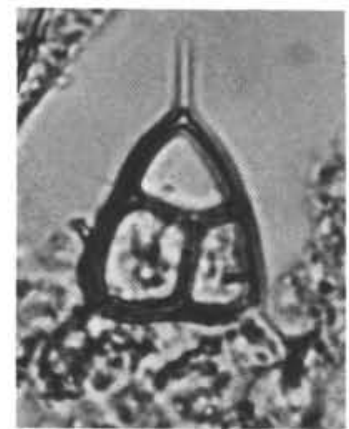

2

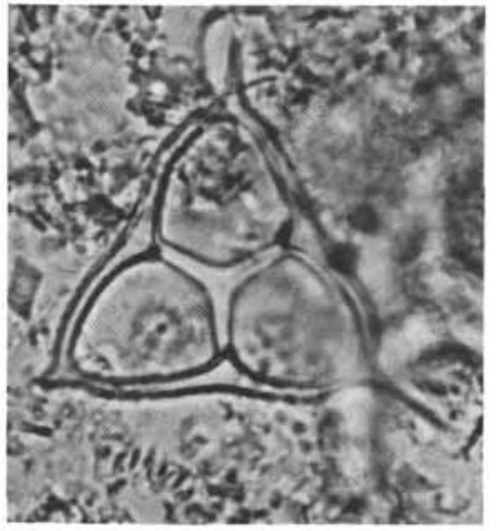

6

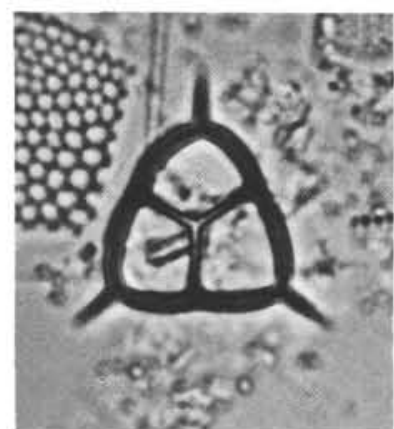

3

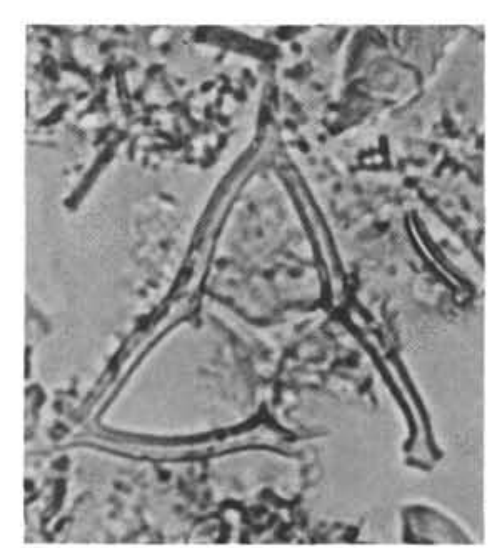

7

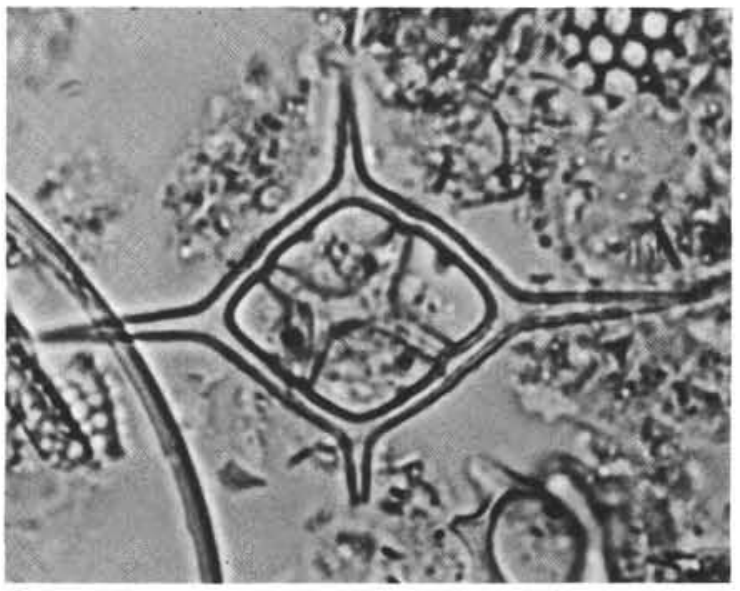

9

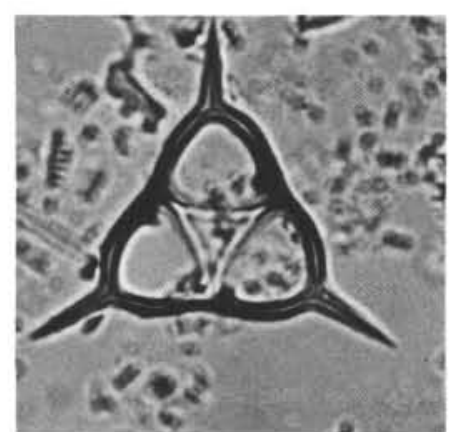

4

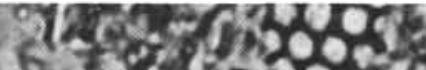

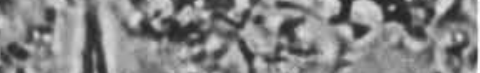

Plate 5. Eocene silicoflagellates from DSDP Leg 95. (Scale bar $=10 \mu \mathrm{m}$.) 1-3. Corbisema jerseyensis Bukry, n. sp., (1) USNM 401479, Sample 612-17-3, 100-101 cm, (2) holotype, USNM 401478, Sample 612-20-5, 100-101 cm, (3) USNM 401480, Sample 612-18-1, 100-101 cm. 4. Corbisema regina Bukry, Sample 612-25-2, 100-101 cm. 5. Corbisema triacantha mediana Bukry above Naviculopsis constricta (Schulz), Sample 612-21-1, 100-101 cm. 6-7. Corbisema sp. A, Sample 612-28-1, 100-101 cm. 8-9. Dictyocha acuta Bukry, high and low focus of USNM 401482, Sample 612-18-1, 100-101 cm. 


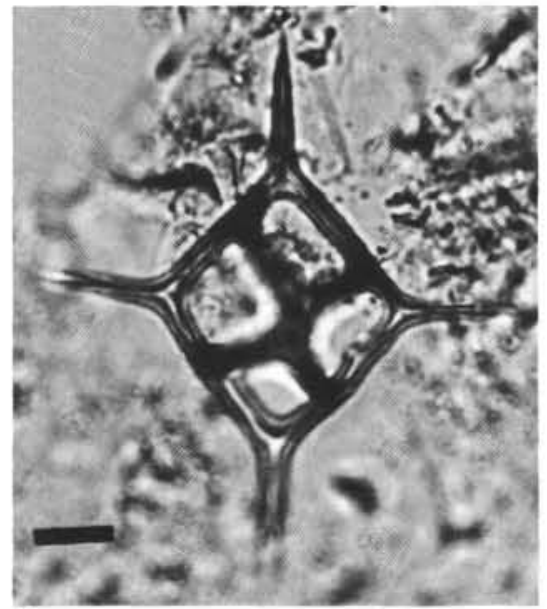

1

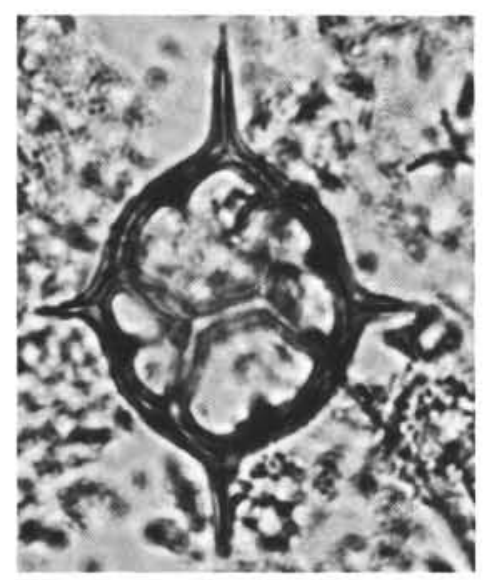

4

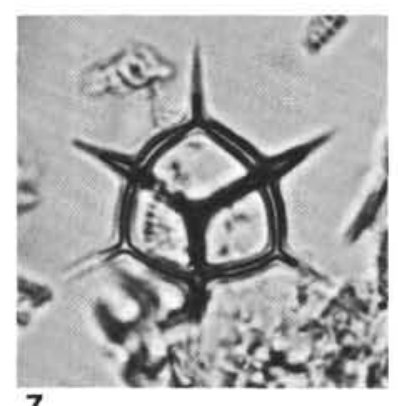

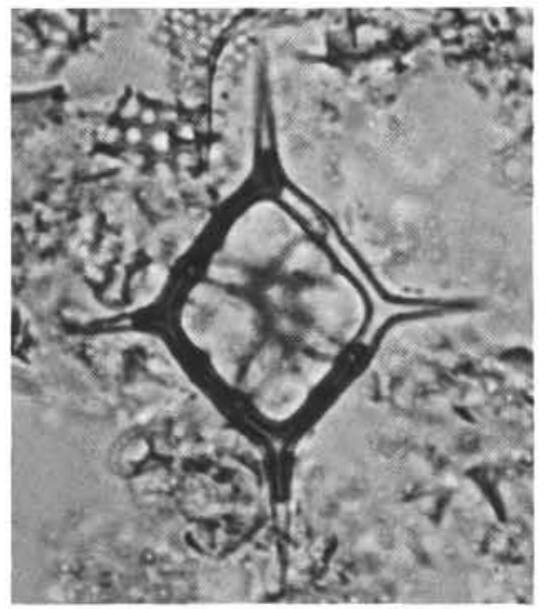

\section{2}

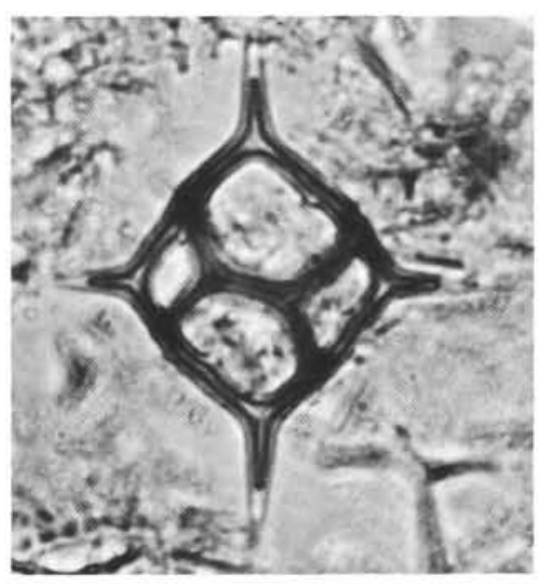

5

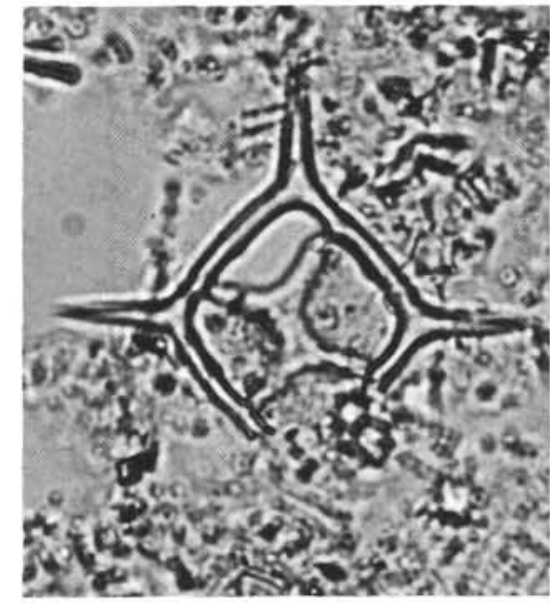

3

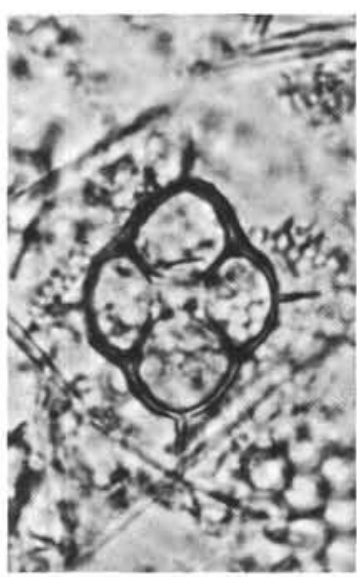

6
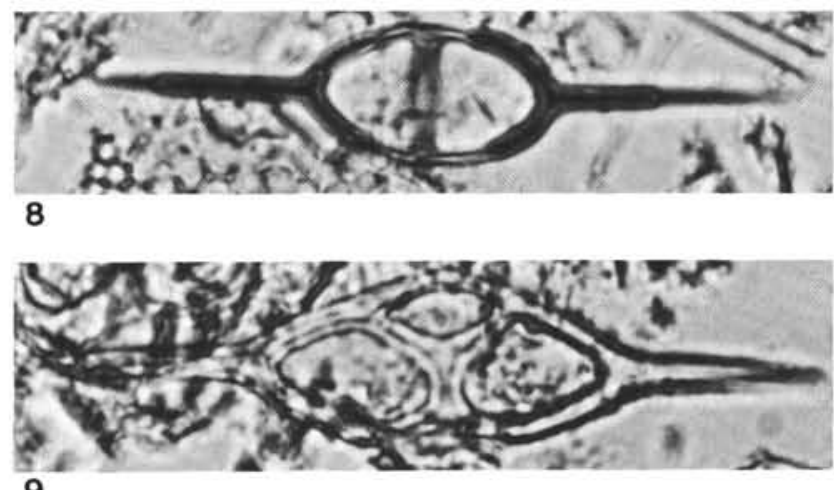

Plate 6. Eocene silicoflagellates from DSDP Leg 95. (Scale bar $=10 \mu \mathrm{m}$.) 1-3. Dictyocha acuta Bukry, n. sp., Sample 612-20-1, 100-101 cm, (1) USNM 401483, (2) holotype, USNM 401481, (3) USNM 401484. 4. Dictyocha byronalis Bukry in Barron, Bukry, and Poore, Sample 612-25-5, 100-101 cm. 5. Dictyocha sp. cf. D. byronalis Bukry in Barron, Bukry, and Poore, Sample 612-18-1, 100-101 cm. 6. Dictyocha deflandrei lobata Bukry, Sample 613-36-5, 100-101 cm. 7. Dictyocha hexacantha Schulz, Sample 612-23-5, 100-101 cm. 8. Naviculopsis biapiculata (Lemmermann), Sample 612-18-1, 100-101 cm. 9. Naviculopsis punctilia punctilia Perch-Nielsen, Sample 613-27-5, 100-101 cm. 


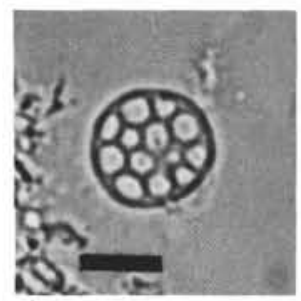

1

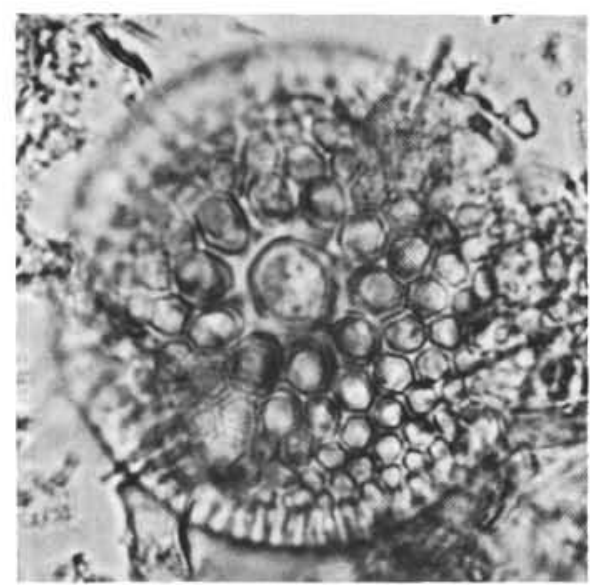

6

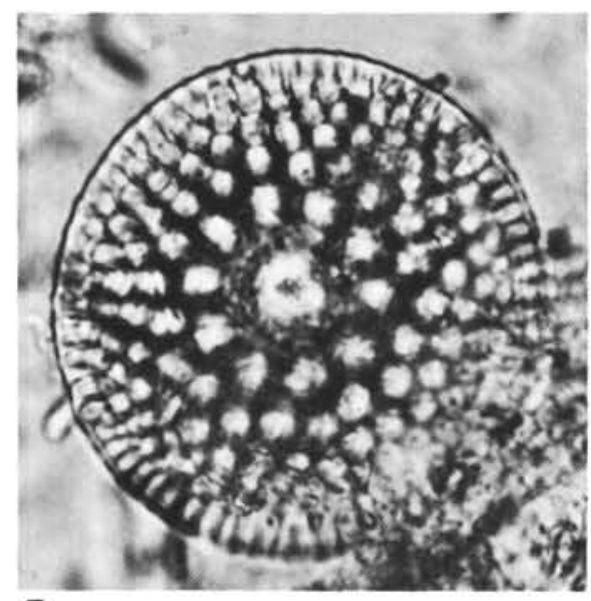

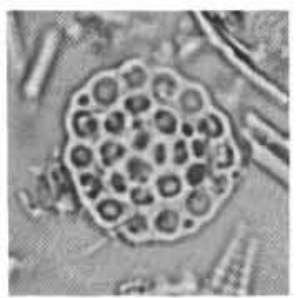

3
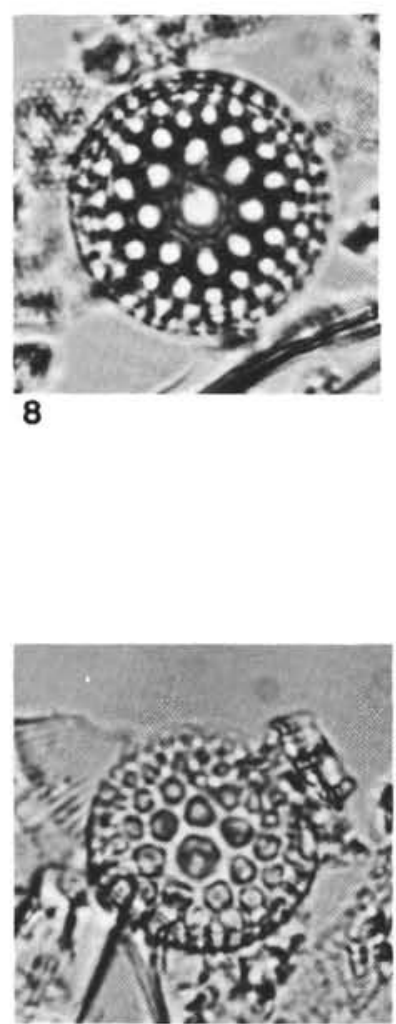

9

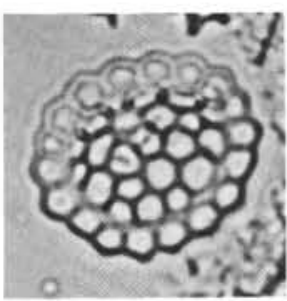

4

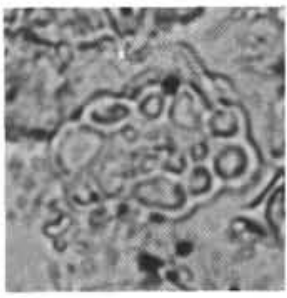

5

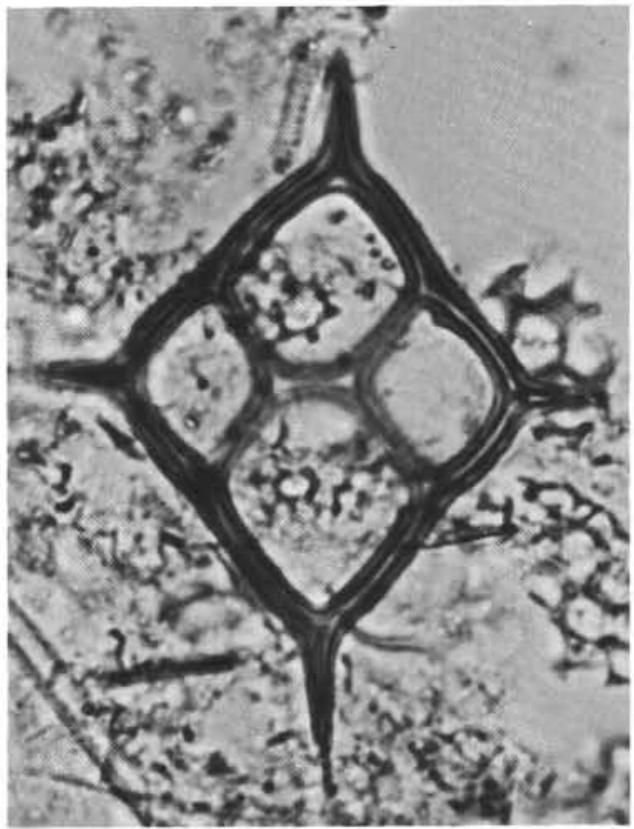

10

7

Plate 7. Eocene diatoms, silicoflagellates, and incertae sedis from DSDP Leg 95. (Scale bar $=10 \mu \mathrm{m}$.) 1. Macrora barbadensis (Deflandre), smooth margin, Sample 612-25-5, 100-101 cm. 2-3. Macrora sp. aff. M. barbadensis (Deflandre), (2) slightly scalloped margin, Sample 61220-5, 100-101 cm, (3) slightly serrate margin and slightly domed center, Sample JM 80010, Paracas Formation, Peru. 4. Macrora stella (Azpeitia), typical serrate margin and domed center, Sample 612-20-5, 100-101 cm. 5. Macrora najae Bukry, Sample 612-23-3, 100-101 cm. 6-9. Coscinodiscus eomonoculus Bukry, n. sp., (6-7) holotype, USNM 401485, Sample 613-36-5, 100-101 cm, high and low focus, (8) USNM 401486, Sample 613-36-5, 100-101 cm, low focus, (9) USNM 401487, Sample 613-34-3, 100-101 cm, high focus. 10. Dictyocha sp. (asperoid), Sample $612-20-5,100-101 \mathrm{~cm}$. 